\title{
Efficient sequestration of lead from aqueous systems by peanut shells and compost: evidence from fixed bed column and batch scale studies
}

\author{
Ghulam Mustafa Shah ${ }^{1}$, Muhammad Imran ${ }^{\text {Corresp., }}{ }^{1}$, Ume Aiman ${ }^{1}$, Muhammad Mohsin Iqbal ${ }^{1}$, Muhammad Akram ${ }^{1}$ \\ Hafiz Rashad Javeed ${ }^{1}$, Atika Waqar ${ }^{1}$, Faiz Rabbani ${ }^{1}$ \\ ${ }^{1}$ Environmental Sciences, COMSATS University Islamabad, Vehari, Punjab, Pakistan \\ Corresponding Author: Muhammad Imran \\ Email address: imranrb@ciitvehari.edu.pk
}

Lead $(\mathrm{Pb})$ is a pervasive contaminant and poses a serious threat to living beings. The present study aims at batch and fixed bed column scale potential of commercial compost (CCB) and peanut shells biosorbents (PSB) for the sequestration of $\mathrm{Pb}$ from contaminated aqueous systems. The PSB and CCB were characterized with FTIR, SEM and Brunauer Emmett-Teller (BET) to get insight of the adsorption behavior of both materials. Fixed bed column scale experiments were performed at steady state flow $(2.5$ and $5.0 \mathrm{ml} / \mathrm{min})$, initial $\mathrm{Pb}$ concentrations ( 25 and $50 \mathrm{mg} / \mathrm{L}$ ) and dosage of each adsorbent ( 3.0 and $6.0 \mathrm{~g} / \mathrm{column}$ ). Columns packed $\left(15.9 \mathrm{~cm}^{2}\right)$ with PSB and CCB have revealed excellent adsorption of $\mathrm{Pb}$ with PSB as compared with CCB. The total volume of injected contaminated water was $1500 \mathrm{ml}$ and $3000 \mathrm{ml}$ at 2.5 and $5.0 \mathrm{ml} / \mathrm{min}$, respectively while total bed volume number was 157. A series of batch experiments with CCB and PSB was conducted at adsorbent dosage (1.25-5.0 g/L), initial Pb level (25-100 mg/L), interaction time (0-180 min) and solution $\mathrm{pH}(4-10)$ at room temperature. Batch scale results revealed that PSB removed $92 \% \mathrm{~Pb}$ from water at $25 \mathrm{mg} \mathrm{Pb/L}$ concentration as compared with CCB (79\%). The presence of competing ions in groundwater showed less $\mathrm{Pb}$ removal as compared with synthetic water. The experimental data were simulated with equilibrium isothermal models: Langmuir, Freundlich, and kinetic models: pseudo first order, pseudo second order and intra-particle diffusion. The Freundlich and pseudo second order models better described the equilibrium and kinetic experimental data, respectively with maximum sorption of $42.5 \mathrm{mg} / \mathrm{g}$ by PSB which is also evident from FTIR functional groups and SEM results. While equilibrium sorption of $\mathrm{Pb}$ onto $\mathrm{CCB}$ was equally explained by Freundlich and Langmuir models. These findings indicate that PSB could be an active and ecofriendly biosorbent for the sequestration of metals from contaminated aqueous systems. 


\title{
Efficient sequestration of lead from aqueous systems by peanut shells and compost: evidence from fixed bed column and batch scale studies
}

\author{
Ghulam Mustafa Shahª, Muhammad Imran ${ }^{\mathrm{a} *}$, Ume-Aiman $^{\mathrm{a}}$, Muhammad Mohsin Iqbala, \\ Muhammad Akram ${ }^{\text {a }}$,Hafiz Rashad Javeed ${ }^{\mathrm{a}}$, Atika Waqar $^{\mathrm{a}}$, Faiz Rabbani ${ }^{\mathrm{a}}$
}

aDepartment of Environmental Sciences, COMSATS University Islamabad, Vehari-Campus, Vehari 61100, Pakistan

$\triangle$ Muhammad Imran, Department of Environmental Sciences, COMSATS University Islamabad, Vehari-Campus Vehari-61100, Pakistan,

Email: imranrb@cuivehari.edu.pk

\section{Abstract}

Lead $(\mathrm{Pb})$ is a pervasive contaminant and poses a serious threat to living beings. The present study aims at batch and fixed bed column scale potential of commercial compost (CCB) and peanut shells biosorbents (PSB) for the sequestration of $\mathrm{Pb}$ from contaminated aqueous systems. The PSB and CCB were characterized with FTIR, SEM and Brunauer Emmett-Teller (BET) to get insight of the adsorption behavior of both materials. Fixed bed column scale experiments were performed at steady state flow (2.5 and $5.0 \mathrm{ml} / \mathrm{min})$, initial $\mathrm{Pb}$ concentrations $(25$ and $50 \mathrm{mg} / \mathrm{L})$ and dosage of each adsorbent (3.0 and $6.0 \mathrm{~g} /$ column). Columns packed $\left(15.9 \mathrm{~cm}^{2}\right)$ with PSB and CCB have revealed excellent adsorption of $\mathrm{Pb}$ with $\mathrm{PSB}$ as compared with $\mathrm{CCB}$. The total volume of injected contaminated water was $1500 \mathrm{ml}$ and $3000 \mathrm{ml}$ at 2.5 and $5.0 \mathrm{ml} / \mathrm{min}$, respectively while total bed volume number was 157. A series of batch experiments with CCB and PSB was conducted at adsorbent dosage (1.25-5.0 g/L), initial Pb level (25-100 mg/L), interaction time (0-180 min) and solution $\mathrm{pH}$ (4-10) at room temperature. Batch scale results revealed that $\mathrm{PSB}$ removed $92 \% \mathrm{~Pb}$ from water at $25 \mathrm{mg} \mathrm{Pb} / \mathrm{L}$ concentration as compared with $\mathrm{CCB}$ (79\%). The presence of competing ions in groundwater showed less $\mathrm{Pb}$ removal as compared with synthetic water. The experimental data were simulated with equilibrium isothermal models: Langmuir, Freundlich, and kinetic models: pseudo first order, pseudo second order and intra-particle diffusion. The Freundlich and pseudo second order models better described the equilibrium and kinetic experimental data, 
32 respectively with maximum sorption of $42.5 \mathrm{mg} / \mathrm{g}$ by PSB which is also evident from FTIR 33 functional groups and $\mathrm{SEM}$ results. While equilibrium sorption of $\mathrm{Pb}$ onto $\mathrm{CCB}$ was equally 34 explained by Freundlich and Langmuir models. These findings indicate that PSB could be an active and ecofriendly biosorbent for the sequestration of metals from contaminated aqueous systems.

37 Keywords: Fixed bed column; Adsorption; Lead sequestration; Peanut shells; Kinetics

\section{Introduction}

Water is very crucial for all the living organisms and is a basic requirement of life. Safe drinking water is essential for sustaining life (Shahid et al. 2021; Natasha et al. 2021). With the passage of time, many natural and anthropogenic activities are polluting freshwater bodies. Several organic and inorganic pollutants are continuously discharged into surface and subsurface water bodies, thereby adversely affecting the ecosystem. In comparison of these water pollutants, heavy metal (HMs) contamination is a major concern. Heavy metals are known as dangerous metals having 63.5-200.6 g atomic weight and five times higher density than water (Abas et al. 2013). Because of their toxicity to plants, animals, and humans, HMs are categorized under environmental pollutants. Heavy metals like Lead, Cadmium, Chromium, Mercury, Arsenic, and Nickel cause a serious threat to human health. These HMs are highly soluble and enter the food chain in variety of ways. These are non-degradable and persistence in nature. Natural (weathering of rocks, volcanos, floods etc.,) and human activities (mining, petroleum refining, tanneries, battery production, metal plating, glass production and pesticides production etc.) induce accumulation of these HMs into the environment (Kadirvelu et al. 2001).

Lead $(\mathrm{Pb})$ is an abundant pollutant in the environment and due to its implications it becomes a major concern worldwide. In America, $\mathrm{Pb}$ is ranked $2^{\text {nd }}$ position among all known hazardous substances (ATSDR 2007). Some sources of $\mathrm{Pb}$ in wastewater are effluents from smelting, tanneries, metal plating, radiator manufacturing, alloy, and battery industries (Kadirvelu et al. 2001). In drinking water, acceptable level of $\mathrm{Pb}$ is $0.05 \mathrm{mg} / \mathrm{L}$ set by WHO and EPA (Arbabi et al. 2015). Moreover, effluents from manufacturing process such as pigments, television tubes, fuel, paints, explosives are also causes of the water contamination with $\mathrm{Pb}$ (Ahalya et al. 2005). When 
62 body through the consumption of $\mathrm{Pb}$ contaminated food chain or water (Abdelsalam 2011). A 63 small amount of $\mathrm{Pb}$ continuously accumulating for extended period results in chronic toxicity and 64 damages to organs (Badmus et al. 2007). Moreover, Pb causes kidney damage, reproductive 65 system, and central nervous system (CNS) in human and causes oxidative stress, damages 66 photosynthetic pigments etc. in plants.

67 Many approaches have been introduced to remove $\mathrm{Pb}$ from wastewater. Among these techniques, 68 ion exchange (Dabrowski et al. 2004), electrolysis, electro-coagulation (Milhajlovic et al. 2015), 69 chemical precipitation (Charerntanyarak 1999), solvent extraction, and adsorption (Iqbal et al. 2021; Imran et al. 2020) etc. are commonly used. Moreover, most of these treatment technologies are expensive, generate secondary pollution, require large number of workers and experts, and show less effectiveness (Abas et al. 2013). However, adsorption is efficient for the sequestration of HMs from contaminated water (Imran et al. 2019).

Metal ions can be removed from wastewater by the adsorption process due to its effective sequestration on the surface of an adsorbent materials (Tariq et al. 2020; Milhajlovic et al. 2015). In this phenomenon, low-cost adsorbents that have higher adsorption potential are utilized. A diversity of indigenously available constituents, e.g., agricultural wastes, natural wastes, and industrial by-products can be employed as economical adsorbents (Atkinson et al. 1998). Huang and $\mathrm{Wu}(1975)$ reported that activated carbon has been extensively employed as an adsorbent for the sequestration of $\mathrm{Pb}$ from contaminated aqueous systems. Activated carbon, on the other hand, is still a costly material due to its widespread application in water and wastewater treatment sectors (Iqbal et al. 2021)). Therefore, for this purpose, more efficient, economically feasible and environment-friendly adsorbents are required. Several scientists have attempted batch scale experiments to examine the adsorption capacity of orange peels (El-Said et al. 2012), cocoa shells (Meunier et al. 2003), banana peels (Annadurai et al. 2002), rice husks (Asrari et al. 2010), saponified melon peels (Chaudhary and Ijaz 2014), eggshell (Hussain and Shariff 2014) and bentonite (Naseem and Tahir 2001) for the elimination of $\mathrm{Pb}$ from polluted water. However, literature shows that there are limited studies performed on column scale for the remediation of $\mathrm{Pb}$ from contaminated water. 
90 Peanut shells (PS) are thrown away as waste product all over the world. They are permeable and

91 contain (hemi)cellulose material, lignin, pectin and slight amount of protein as well as a very 92 complicated combination of polymeric organic compounds and have high electrolytic ability (Shah 93 et al. 2018; Kocasoy amd Guvener 2009). These properties can make them effective biosorbent. 94 These shells are plentiful, affordable, easy to process, and incredibly efficient constituents. 95 According to Chaudhry and Ijaz (2014), cost effective adsorbents should be commonly accessible 96 with high selectivity and large capacity for the sequestration of contaminants. Other criteria that is 97 often overlooked is that no or slightly harmful and toxic chemicals are used in the synthesis of 98 these biosorbents. Solid wastes e.g., compost and PS can be used to obtain all these benefits. 99 Furthermore, reuse of these solid wastes for the sequestration of HMs ions can eliminate the issue 100 of disposal of hazardous effluents while also increasing economic benefits (Tahiruddin and 101 Rahman 2013). The goals of present study were to: (i) assess the solid wastes (i.e., peanut shells 102 and commercial compost to remove $\mathrm{Pb}$ from wastewater) adsorption potential and (ii) evaluate 103 adsorption of $\mathrm{Pb}$ by using these wastes at column and batch scale under variety of adsorbate concentrations, adsorbent dosage, and solution $\mathrm{pH}$ and interaction time

\section{Materials \& Methods}

\section{Preparation of adsorbents}

107 The peanut shells (PS) were gathered from the local market in Vehari. The PS were rinsed with 108 distilled water to get rid of the adhered particles and dust. The PS were dried in an oven at $70^{\circ} \mathrm{C}$

109 for 36 hours. Subsequently, the PS were grounded and sieved ( $1 \mathrm{~mm} \mathrm{mesh}$ ). The ground material 110 (peanut shells as biosorbent: PSB) was stored in plastic container for further applications. The 111 commercial compost biosorbent (CCB) was obtained from a company 'PlantFert'. The CCB was 112 prepared from vegetables waste as per company instructions.

\section{Characterization of adsorbents}

114 Representative samples of PSB and CCB were characterized using Fourier transform infrared 115 (FTIR) spectroscopy for functional groups determination (Imran et al. 2021). The surface 116 morphology of PSB and CCB was obtained with scanning electron microscopy (SEM) while the 117 adsorbent samples were analyzed with Brunauer Emmett-Teller (BET) to find pore volume and 118 surface area from $\mathrm{N}_{2}$ adsorption/desorption isotherms. 
119 Infrared spectra of pristine PSB and CCB were obtained in absorbance mode from wavenumber

$120700-4000 \mathrm{~cm}^{-1}$ at resolution of $2 \mathrm{~cm}^{-1}$. The FTIR spectra were achieved using a Matson Polaris

121 FTIR spectrophotometer. Prior to FTIR analysis, PSB and CCB were milled with KBr to form fine

122 powder and compressed into thin pellets. The SEM images for surface morphology were obtained

123 using a TESCAN Vega TS 5136LM at $20 \mathrm{kV}$. The samples for SEM analysis were coated in gold

124 with a Balzers' Spluttering device. The Brunauer-Emmett-Teller (BET) surface area and pores

125 related information of both PSB and CCB were measured with a Tristar 3000 (Micromeritics)

126 analyzer. Porosity (\%) of the PSB and CCB was measured following Shah et al. (2019).

\section{Preparation of synthetic wastewater}

128 Lead nitrate $\left(\mathrm{Pb}\left(\mathrm{NO}_{3}\right)_{2}\right)$ salt was used for the preparation of $\mathrm{Pb}$ stock solution. For $1000 \mathrm{mg} / \mathrm{L} \mathrm{Pb}$ 129 stock solution in a $1000 \mathrm{~mL}$ volumetric flask, $1.60 \mathrm{~g}$ of $\mathrm{Pb}\left(\mathrm{NO}_{3}\right)_{2}$ was thoroughly mixed in 500

$130 \mathrm{~mL}$ distilled water and final volume was made $1 \mathrm{~L}$. Different sub-stocks of 25- $100 \mathrm{mg} / \mathrm{L}$ were 131 prepared from this stock solution. For the $\mathrm{pH}$ adjustment, a few drops of $0.5 \mathrm{M} \mathrm{NaOH} / \mathrm{HCl}$ solution 132 were added to maintain the $\mathrm{pH}$ 6.0. Because dissolved $\mathrm{Pb}$ ions precipitate at high $\mathrm{pH}$, maximal 133 adsorption of $\mathrm{Pb}$ occurs at $6.0 \mathrm{pH}$ (Imran et al. 2020; Ahmed et al. 2016).

\section{Fixed bed column scale removal of $\mathrm{Pb}$ and reusability of PSB}

135 The fixed bed column scale experiments for $\mathrm{Pb}$ removal were carried out in plexiglass columns.

136 The experiment was conducted at steady state in duplicate sets. The column scale arrangement

137 with the dimensions (14.5 cm length and $4.5 \mathrm{~cm}$ internal diameter) is presented in Figure 1 . The 138 adsorbent biomass (3.0 and $6.0 \mathrm{~g} /$ column) was packed as a central layer between acid-washed 139 quartz sand (0.1-0.2 mm). Wet packing was adopted to release the trapped air between the particles 140 and to get rid of disturbance during flow of contaminated water in the column. At the inner bottom 141 and topmost position, cloth filter was used to improve the flow distribution, prevent adsorbent loss, 142 and avoid clogging of the openings used for capillaries carrying $\mathrm{Pb}$ contaminated water at inlet 143 and effluent at outlet. Filter was also used at the bottom and top of the adsorbent layer as shown 144 in Figure 1. At the start, distilled water was run for $30 \mathrm{~min}$ through the columns to flush the 145 columns. Two different initial concentrations of $\mathrm{Pb}(25$ and $50 \mathrm{mg} / \mathrm{L})$ were injected through the 146 columns at flow rate 2.5 and $5.0 \mathrm{ml} / \mathrm{min}$ at $\mathrm{pH} 6$ (optimum $\mathrm{pH}$ level at batch scale). At outlet side, 147 effluent was collected in plastic bottles by gravity. The effluent was collected after 15, 30, 60, 120, $148180,240,300,360,420,480,540$ and 600 min to determine the residual $\mathrm{Pb}$ concentration in the 
149 water after attachment of $\mathrm{Pb}$ at PSB and CCB surface. A peristaltic pump was used to inject 150 contaminated water at a uniform flow rate at inlet side while at outside pump was not used just 151 effluent was collected by gravity. In Figure 1, acronym R1 represents replication one and R2 152 indicates replication two of the column experimentation. To estimate the reusability of PSB and $153 \mathrm{CCB}$, the columns were emptied after experimental run at $25 \mathrm{mg} / \mathrm{L}$ and the used PSB and CCB 154 were rinsed with $2 \% \mathrm{HCl}$ solution, filtered by adding distilled water and used for repacking before 155 starting injection of $25 \mathrm{mg} / \mathrm{L}$ concentration again in the columns. The column scale removal and 156 reusability of $\mathrm{PSB}$ and $\mathrm{CCB}$ for $\mathrm{Pb}$ sequestration were calculated based on the residual 157 concentration and initial concentration of $\mathrm{Pb}$ in water.

\section{Batch experiments}

160 Batch experiments were performed in the Environmental Sciences laboratory of COMSATS 161 University Islamabad (CUI), Vehari Campus. Digital weighing balance was used to weigh three 162 different adsorbent doses (1.25, 2.5, and $5.0 \mathrm{~g} / \mathrm{L})$ of both adsorbents (PSB and CCB). In $250 \mathrm{~mL}$ conical flasks, $100 \mathrm{~mL}$ of different concentrations $(25,50,75$, and $100 \mathrm{mg} / \mathrm{L})$ of $\mathrm{Pb}$ contaminated solution and weighed doses of adsorbents were added. Duplicate sets were prepared and placed on a mechanical shaker at $150 \mathrm{rpm}$ and room temperature $\left(28^{\circ} \mathrm{C}\right)$. At different time intervals $(15,30$, 60, and $120 \mathrm{~min}$ ), samples were taken and filtered using Whatman filter papers-42. The filtered samples were used to determine the residual concentration of $\mathrm{Pb}$ in water samples. Samples of initial concentrations of sub solution (without addition of biosorbents) were also stored for analysis. For the determination of $\mathrm{pH}$ effect on the sequestration of $\mathrm{Pb}$ from contaminated water, different $\mathrm{pH}$ values (4-10) were adjusted using $0.5 \mathrm{M} \mathrm{NaOH} / \mathrm{HCl}$ solutions rest while of the parameters e.g., initial concentration (IC), temperature and adsorbent dose were kept constant. Atomic Absorption Spectrophotometer (AAS) was used to measure the concentration of residual

$173 \mathrm{~Pb}$ in samples.

\section{Impact of coexisting ions on $\mathrm{Pb}$ removal from water}

175 In groundwater and wastewater, there exists several other ions which interfere in the adsorption of contaminant from water onto the adsorbent surface. Therefore, in the present study two groundwater samples (GW1 and GW2) having different concentration of cations and anions collected from Vehari were used to evaluate the impact of coexisting ions in water for the sequestration of $\mathrm{Pb}$. The groundwater samples were analysed for electrical conductivity (EC), total 
180 dissolved salts (TDS), $\mathrm{pH}$, sodium $(\mathrm{Na})$, potassium $(\mathrm{K})$, calcium $(\mathrm{Ca})$, magnesium $(\mathrm{Mg})$, carbonate

$181\left(\mathrm{CO}_{3}\right)$, bicarbonate $\left(\mathrm{HCO}_{3}\right)$, Chlorine $(\mathrm{Cl})$, sulphate $\left(\mathrm{SO}_{4}\right)$, nitrate $\left(\mathrm{NO}_{3}\right)$ and $\mathrm{Pb}$. The EC, TDS and

$182 \mathrm{pH}$ were measured with respective EC, TDS, and $\mathrm{pH}$ meters. The $\mathrm{Na}, \mathrm{K}$ and Ca were measured

183 using Flame photometer while $\mathrm{SO}_{4}$ and $\mathrm{NO}_{3}$ concentration was measured with calorimetric

184 method. The concentration of $\mathrm{Cl}, \mathrm{CO}_{3}$ and $\mathrm{HCO}_{3}$ was measured with titration method Estefan

185 (2013) while $\mathrm{Mg}$ and $\mathrm{Pb}$ were measured using atomic absorption spectrophotometer.

186 First groundwaters containing $\mathrm{Pb}(\mathrm{GW} 1=80 \mathrm{ug} / \mathrm{L}, \mathrm{GW} 2=57 \mathrm{ug} / \mathrm{L})$ were treated with $\mathrm{PSB}$ and

$187 \mathrm{CCB}$ at optimum conditions and subsequently $\mathrm{Pb}$ concentration $(25 \mathrm{mg} / \mathrm{L})$ was developed in both 188 groundwater samples and $\mathrm{Pb}$ removal was evaluated in the presence of different cations and anions

189 in water. The characteristics of GW1 and GW2 have been presented in Table 1. The results of

190 batch scale adsorption experiments carried out in distilled water (DW) and groundwater samples

191 at $\mathrm{Pb}$ concentration $(25 \mathrm{mg} / \mathrm{L}$ and $50 \mathrm{mg} / \mathrm{L})$ were compared to evaluate the impact of competing

192 ions in water on $\mathrm{Pb}$ removal.

193 Data analysis

194 The initial and final concentrations of $\mathrm{Pb}$ ions in water samples were measured using AAS. The 195 equilibrium adsorption $q_{e}(\mathrm{mg} / \mathrm{g})$ of $\mathrm{Pb}$ ions onto PSB and CCB was estimated with Eq. 1 (Imran 196 et al. 2021; Shah 2019; Edokpayi et al. 2015).

$$
q_{e}=\left(\frac{C_{i}-C_{e}}{W}\right) \times V
$$

In Eq. (1), $\mathrm{C}_{\mathrm{i}}$ is the $\mathrm{IC}$ and $\mathrm{C}_{\mathrm{e}}$ is the residual concertation $(\mathrm{mg} / \mathrm{L})$ of $\mathrm{Pb}$ ions in water, $V$ is the volume of $\mathrm{Pb}$ contaminated water $(\mathrm{L}), \mathrm{W}$ is the mass $(\mathrm{g})$ of the adsorbents (PSB and $\mathrm{CCB}$ ) and $q_{e}$ represents the amount of adsorbate $(\mathrm{Pb})$ ions attached on the surface of PSB and $\mathrm{CCB}$ at equilibrium. To determine the kinetic adsorption $q_{t}$ at time $t$, Ce in Eq. (1) was replaced with residual concentration $\left(C_{t}\right)$ at time $t$.

203 The percentage removal $(\mathrm{R} \%)$ of $\mathrm{Pb}$ ions from contaminated water by PSB and $\mathrm{CCB}$ at column

204 and batch scale was found from initial and final concentration $\left(C_{f}\right)$ of $\mathrm{Pb}$ using Eq. (2) 


$$
R(\%)=\left(\frac{C_{i}-C_{f}}{C_{i}}\right) \times 100
$$

206 The total volume of $\mathrm{Pb}$ containing solution $\left(V_{t}\right)$ injected to each column was calculated from the

207 multiplication of flow rate $(Q)$ and total injection time $t_{\text {total }}\left(V_{t}=Q t_{\text {total }}\right)$. The total mass

$208\left(m_{\text {total }}\right)$ of metal ions ( $\left.\mathrm{mg}\right)$ injected to the column was found using Eq. (3) while column scale

209 adsorption was estimated from Eq. (1) by replacing $V$ with $Q t_{\text {total }}$.

$$
m_{\text {total }}=\frac{C_{i} Q t_{\text {total }}}{1000}
$$

\section{Adsorption kinetics modeling}

212 Kinetic studies are employed for the optimization of different operating conditions for the 213 adosorption process. Literature shows that different kinetic models are proposed to explain the 214 reaction sequence and adsorption behavior (Imran et al. 2020; Iqbal et al. 2021). In the present 215 study, pseudo first order (PFO), pseudo-second order (PSO), and intra-particle diffusion (IPD) 216 kinetic models were used for the kinetics of $\mathrm{Pb}$ ions adsorption onto PSB and $\mathrm{CCB}$. The correlation 217 coefficients $\left(\mathrm{R}^{2}\right)$ were used to determine the applicability of these kinetic models. The model is 218 most relevant to data when the $\mathrm{R}^{2}$ value is high (close to 1.0) (Imran et al. 2019).

219 The PFO kinetic model is based on the notion that the change in contaminant concentration 220 overtime is proportional to power one which has been presented in linear form (Eq. 4).

$$
\log \left(\mathrm{q}_{\mathrm{e}}-\mathrm{q}_{\mathrm{t}}\right)=\log q_{e}+\frac{k_{t}}{2.303} t
$$

222 In Eq. (4), $\mathrm{q}_{\mathrm{e}}$ and $\mathrm{q}_{\mathrm{t}}$ represent the adsorption capacity of PSB and CCB $\left(\mathrm{mg} \mathrm{g}^{-1}\right)$ at equilibrium and 223 time $\mathrm{t}$, respectively, $k_{l}$ represents rate constant $\left(\mathrm{L} \mathrm{min}^{-1}\right)$ and $t$ represents time duration (min). Table 2242 shows the values of $k_{l}, \mathrm{q}_{\mathrm{e}}$, and $\mathrm{R}^{2}$ which is a correlation coefficient between experimental and 225 model values. The findings indicated that a plot of $\log \left(\mathrm{q}_{\mathrm{e}}-\mathrm{q}_{\mathrm{t}}\right)$ vs $t$ using the Lagergren PFO model 226 yields a straight line with a low correlation coefficient $\left(\mathrm{R}^{2}\right)$. In comparison to the experimental 227 results, the PFO kinetic model projected much lower values of the equilibrium adsorption capacity $228\left(\mathrm{q}_{\mathrm{e}}\right)$. The results showed that the PFO kinetic model is incompatible with the kinetic data of $\mathrm{Pb}$ 229 adsorption. The PFO kinetic model is not usually appropriate for entire data range of interaction 
230 time, but it explains well the adsorption mechanism at the start of the interaction between the

231 adsorbent and contaminant (McKay and Ho 1999).

232 The PSO kinetic model explains the contaminant adsorption mechanism throughout the whole 233 interaction time. The PSO may be expressed in linear form by Eq. (5):

$$
\frac{\mathrm{t}}{\mathrm{q}_{\mathrm{t}}}=\frac{1}{\mathrm{k}_{2} \mathrm{q}_{\mathrm{e}}^{2}}+\frac{1}{\mathrm{q}_{\mathrm{e}}} t
$$

235 Where $k_{2}\left(\mathrm{~g} \mathrm{mg}^{-1} \mathrm{~min}^{-1}\right)$ indicates the PSO rate constant of the contaminant adsorption process. 236 The values of $k_{2}\left(\mathrm{~g} \mathrm{mg}^{-1} \mathrm{~min}^{-1}\right)$ and $\mathrm{q}_{\mathrm{e}}\left(\mathrm{mg} \mathrm{g}^{-1}\right)$ were determined by making a plot of $\mathrm{t} / \mathrm{q}_{\mathrm{t}}$ against

237 t. The values of PSO model parameters and $\mathrm{R}^{2}$ for adsorption of $\mathrm{Pb}$ have been presented in Table

238 2. The estimated and experimental $\mathrm{q}_{\mathrm{e}}$ values were found to be closer to each other with high $\mathrm{R}^{2}$.

239 Thereafter, PSO kinetic model fits well with the kinetic adsorption of Pb ions on PSB and CCB as 240 compared with PFO kinetic model. These findings corroborate the previously published findings

241 (Sadaf and Bhatti 2011). Several stages are involved in the attachment of $\mathrm{Pb}$ molecules from 242 contaminated water to the surface of adsorbent materials. The rate-controlling step in a batch 243 experiment system includes quick and continuous stirring might be film diffusion, intra-particle 244 diffusion (Eq. 6), or a combination of both processes.

$$
. \mathrm{q}_{\mathrm{t}}=K_{\text {dif }} t^{0.5}+C
$$

In Eq. (6), $\mathrm{C}=$ intercept which characterizes boundary layer thickness and $k_{d i f}\left(\mathrm{mg} \mathrm{g}^{-1} \mathrm{~min}^{-1 / 2}\right)=\operatorname{IPD}$ rate constant. Table 2 shows the $k_{d i f}$ and $C$ values for $\mathrm{Pb}$ adsorption onto PSB and CCB. According to IPD hypothesis, curve between $\mathrm{q}_{\mathrm{t}}$ and $\mathrm{t}^{0.5}$ should be linear. If IPD is involved in the adsorption of a contaminant, there exists straight line between a plot of contaminant adsorbed per unit mass of biosorbent $\left(q_{t}\right)$ and $t^{0.5}$ (Bhattacharyya and Gupta 2006). The low value of $R^{2}$ suggests that the $\mathrm{Pb}$ ion attachment onto the PSB and CCB is not influenced IPD.

\section{Adsorption equilibrium isotherms}

254 The adsorption isotherms are employed to test the adsorbents adsorption capacity for a certain 255 contaminant (Imran et al. 2020). The adsorption isotherm is a property of a system at a given 256 temperature (Iqbal et al. 2021; Shah et al. 2019; Poulopoulos and Inglezakis 2006). Adsorption

257 isotherms may be predicted using a variety of models. Langmuir and Freundlich equilibrium 
258 sorption isotherms are the most widely utilized models for pollutant adsorption from wastewater 259 (Tariq et al. 2020).

260 In Langmuir isotherm (Eq. 7), monolayer adsorption of a contaminant onto the surface with a

261 limited number of sites available for contaminant adsorption is considered.

$$
\mathrm{q}_{\mathrm{e}}=\frac{\mathrm{q}_{\max } \mathrm{K}_{\mathrm{L}} \mathrm{C}_{\mathrm{e}}}{1+K_{L} C_{e}}
$$

263 Where $\mathrm{q}_{\max }$ represents the maximum adsorption of $\mathrm{Pb}$ ions onto $\mathrm{PSB}$ and $\mathrm{CCB}, \mathrm{K}_{\mathrm{L}}=$ Langmuir 264 model constant and $\mathrm{C}_{\mathrm{e}}=\mathrm{Pb}$ concentration in solution $(\mathrm{mg} / \mathrm{L})$ at equilibrium

265 Langmuir isotherm model in linearized form has been given in Eq. (8) to find the model 266 parameters. The values of the Langmuir model parameters, $\mathrm{q}_{\max }$ and $\mathrm{K}_{\mathrm{L}}$ were found by using the 267 slope and intercept of the linear plot of $\mathrm{C}_{\mathrm{e}} / \mathrm{q}_{\mathrm{e}} \mathrm{vs} \mathrm{C}_{\mathrm{e}}$.

$$
\frac{\mathrm{C}_{\mathrm{e}}}{\mathrm{q}_{\mathrm{e}}}=\frac{1}{q_{\max } K_{L}}+\frac{1}{q_{\max } C_{e}}
$$

270

The biosorbent surface might be monolayer or/and multilayer. It is reported that Freundlich isotherm model (Eq. 9) is applicable for multilayer adsorption and it assumes contaminant interaction with a heterogeneous surface having a non-uniform sorption energy distribution throughout the surface.

$$
q_{e}=K_{f} C_{e}^{1 / \mathrm{n}}
$$

275 Where $q_{e}=$ equilibrium sorption of $\mathrm{Pb}$ per mass of the $\mathrm{PSB}$ and $\mathrm{CCB}(\mathrm{mg} / \mathrm{g}), \mathrm{Ce}=$ aqueous 276 concentration of $\mathrm{Pb}$ at equilibrium $(\mathrm{mg} / \mathrm{L}), K_{f}$ and $\mathrm{n}$ are Freundlich model constants related to the 277 adsorption capacity and the adsorption intensity, respectively.

278 To determine the values of model parameters, linearized form of Freundlich isotherm (Eq. 10) 279 model was used. The slope and intercept of the curve of $\ln q e$ vs $\ln C e$ were considered to derive 280 the Freundlich equilibrium constants $K_{f}$ and $n$. 


$$
\ln q_{e}=\ln K_{f}+\frac{1}{\mathrm{n}} \ln C_{e}
$$

\section{Results and Discussion}

\section{Characterization of Adsorbents}

284 The surface morphology of PSB and CCB using scanning electron microscope has been presented 285 in Figure 2a-b. The SEM results illustrated that PSB and CCB have porous surface with pores 286 having variation in size and possessed irregular shapes containing capillary tubes that might help 287 to trap metal ions through diffusion. Overall, there is more aggregation of particles in case of CCB 288 as compared with PSB which might lead to lower Pb adsorption by CCB.

Figure 2c displays the Fourier transform infrared (FTIR) spectroscopic results to find the functional groups existing on PSB and CCB surface. As shown in Figure 2c, the FTIR spectra indicated broad band at $3308 \mathrm{~cm}^{-1}$ which represented $-\mathrm{OH}$ groups. The absorbance peak observed at wavenumber $2920-2849 \mathrm{~cm}^{-1}$ indicates aliphatic C-H group. The one peak observed at 1400 $\mathrm{cm}^{-1}$ represents alkanes $(\mathrm{C}-\mathrm{H})$ bending. The absorption peaks observed at wavenumber 1518-1634 $\mathrm{cm}^{-1}$ represent stretching of $\mathrm{C}=\mathrm{C}$. The presence of these functional groups on PSB and CCB surface is responsible for the $\mathrm{Pb}$ adsorption from contaminated water. However, there is difference in absorbance peak and wavenumber between PSB and CCB which might help in their different $\mathrm{Pb}$ adsorption potential.

Brunauer Emmet-Teller (BET) analysis was performed to find the surface area and pore size of PSB and CCB adsorbents. The $\mathrm{N}_{2}$-adsorption/desorption isotherms obtained from BET analysis were used to determine the pores related information (size, volume, porosity) and BET surface area of PSB and CCB (Figure 2d). There is difference in adsorption/desorption curves which reveals the porous nature of both adsorbents. The BET results revealed that PSB exhibits surface area of $226.8 \mathrm{~m}^{2} / \mathrm{g}$. The average particle and pore size of PSB was 26.5 and $3.3 \mathrm{~nm}$, respectively.

304 While PSB has $5.11 \%$ porosity which contributes in the electrostatic attachment and diffusive movement of $\mathrm{Pb}$ onto PSB surface. The surface area of CCB was $126.1 \mathrm{~m}^{2} / \mathrm{g}$ with particle size of $45 \mathrm{~nm}$ and pore size of $3.5 \mathrm{~nm}$. 
308 It was important to assess the impact of controlling parameters on the removal of $\mathrm{Pb}$ from fixed

309 bed column with both adsorbents. The column scale removal of contaminants is governed by flow

310 rate, inlet concentration, bed depth and inner diameter of the column (Canteli et al. 2014). In the

311 present study, the impact of flow rate $(2.5$ and $5.0 \mathrm{ml} / \mathrm{L})$, initial concentration of $\mathrm{Pb}(25$ and 50

$312 \mathrm{mg} / \mathrm{L}$ ) and dose (bed height= 0.65 and $1.2 \mathrm{~cm} /$ column) of PSB and CCB (3.0 and $6.0 \mathrm{~g} / \mathrm{column})$

313 was evaluated on the shape of breakthrough curves.

\section{Impact of flow rate on column scale $\mathbf{P b}$ sequestration}

315 Figure $3 \mathrm{a}$ presents the breakthrough curves for the removal of $\mathrm{Pb}$ onto PSB and CCB at two 316 different flow rates $(2.5$ and $5 \mathrm{ml} / \mathrm{min})$ while other parameters; dose of PSB and CCB was 3.0

$317 \mathrm{~g} /$ column $(0.65 \mathrm{~cm} /$ column $)$ were kept constant constant. The results revealed that when flow rate

318 is increased, there is decline in the uptake of $\mathrm{Pb}$ ions by both adsorbents (PSB and CCB) due to

319 negative effect of flow rate on mass transfer efficiency. The volume of injected $\mathrm{Pb}$ containing 320 water at 2.5 and $5.0 \mathrm{ml} / \mathrm{min}$ was $1500 \mathrm{ml}$ and $3000 \mathrm{ml}$, respectively. While bed volume (BV) 321 number which is the ratio of total volume of contaminated water fed to the column and volume of

322 adsorbent bed was 157. The results show that volume of treated effluent is reduced at higher flow 323 rate because breakthrough curve is obtained earlier, and adsorbents get saturated in short time at 324 high flow rate of injected water. It is attributed to the low interaction time between the adsorbent material and $\mathrm{Pb}$ ions which ultimately prevents complete saturation of the active sites thereby leading a decline in adsorption of $\mathrm{Pb}$ ions. Similar trend was reported by other investigators in literature (Naeem et al. 2019; Cantelli et al. 2014; Caprine et al. 2013). The results show that Pb ions adsorption on PSB strongly depends on the flow rate at which contaminated water is being injected to the column. The PSB and CCB takes more time to get saturated when there is low flow rate and sorption increased steadily as compared with injection of $\mathrm{Pb}$ containing water at high flow rate. The injection time must be extended when contaminant is injected at low flow rate because adsorption sites are saturated gradually (Naeem et al. 2019). Overall, PSB showed more removal of $\mathrm{Pb}$ ions as compared with $\mathrm{CCB}$. At the start, there is negligible difference in $\mathrm{Pb}$ removal by $\mathrm{PSB}$

334 and CCB (first $30 \mathrm{~min}$ ) while later on e.g. at $300 \mathrm{~min}$, PSB removed 47\% $\mathrm{Pb}$ and CCB removed

$33532.4 \% \mathrm{~Pb}$ from contaminated water at constant flow rate $(2.5 \mathrm{ml} / \mathrm{min})$. However, results showed 336 that at the same (300 min) PSB and CCB showed just 23.7\% and 2.5\% removal, respectively when

337 at flow rate $5.0 \mathrm{ml} / \mathrm{min}$. Similarly, Yahya et al. (2020) studied that the decline in metal ions onto 338 the cashew nutshell adsorbent was observed when flow rate was increased at a fixed adsorbent 
339 bed. It is due to the less time available between adsorbents (PSB and CCB) and metal ions for

340 interaction which reduces the adsorbent saturation. While at lower flow rate metal ions were

341 removed efficiently. Xu et al. (2013) reported that at lower flow rate film resistance and thickness

342 was increased which contributes to higher metal removal from contaminated water. Priya and

343 Radha (2016) reported that the adsorption was significantly affected by varying flow rate. As flow

344 rate increases the film resistance is decreased which reduces the sequestration of contaminants

345 from aqueous systems.

346 Effect of initial concentration of $\mathrm{Pb}$ on column scale sequestration

347 Figure $3 \mathrm{~b}$ displays the effect of $\mathrm{Pb}$ initial concentration ( 25 and $50 \mathrm{mg} / \mathrm{L}$ ) on its removal by PSB

348 and CCB at column scale when flow rate is $2.5 \mathrm{ml} / \mathrm{min}$, bed height is $0.65 \mathrm{~cm}(3.0 \mathrm{~g} /$ column $)$ and

$349 \mathrm{pH}$ of $\mathrm{Pb}$ containing water is $\mathrm{pH}-6$. The mass of $\mathrm{Pb}$ fed to the adsorbents was $37.5 \mathrm{mg}$ and 150

$350 \mathrm{mg}$ when water was injected at 25 and $50 \mathrm{mg} / \mathrm{L}$, respectively. The results show that the change in

351 concentration gradient has significant impact on the saturation of PSB and $\mathrm{CCB}$ and their $\mathrm{Pb}$

352 removal (\%) from contaminated water. There is decline in $\mathrm{Pb}$ removal when its concentration was

353 changed from $25-50 \mathrm{mg} / \mathrm{L}$. This decline in $\mathrm{Pb}$ removal at elevated concentration of $\mathrm{Pb}(50 \mathrm{mg} / \mathrm{L})$

354 is accredited to the saturation of available sorption sites on PSB and CCB beyond a certain initial

355 level of metal ions. At time $240 \mathrm{~min}$, PSB and CCB showed $63.4 \%$ and $50.8 \% \mathrm{~Pb}$ removal,

356 respectively when initial $\mathrm{Pb}$ concentration was $25 \mathrm{mg} / \mathrm{L}$ while these adsorbents showed $54.8 \%$ and

$35743.2 \% \mathrm{~Pb}$ removal, respectively at the same time (240 min) but at $50 \mathrm{mg} / \mathrm{L}$ initial $\mathrm{Pb}$ concentration.

358 However, $\mathrm{Pb}$ adsorption onto PSB and $\mathrm{CCB}$ increased with increase in initial concentration of $\mathrm{Pb}$

359 in water. This enhanced $\mathrm{Pb}$ adsorption at elevated initial $\mathrm{Pb}$ level is because of higher utilization

360 of active sites at elevated $\mathrm{Pb}$ concentration. This earlier exhaustion of the PSB and CBB active

361 sites at elevated $\mathrm{Pb}$ level is attributed to the fact that high $\mathrm{Pb}$ concentration caused quick saturation

362 of the sorbent. Results (Figure 3b) reveal that the shape of curves by PSB and CCB at higher

363 concentration $(50 \mathrm{mg} / \mathrm{L})$ is more pronounced and steepness of the slope is also increased. Swapna

364 Priya and Radha (2016) reported that the adsorption capacity decreased from 10.26 to $9.90 \mu \mathrm{g} \mathrm{g}^{-1}$

365 when the solution initial concentration decreased from 600 to $200 \mu \mathrm{g} \mathrm{L}{ }^{-1}$. However, there is slower

366 saturation of adsorbent materials at lower initial concentration as compared with high initial

367 concentration. Similarly, Bharathi and Ramesh (2013) reported the removal of contaminant

368 decreased with increasing initial concentration which is due to decline in exhaustion and 
369 breakthrough time. Dorado et al. (2014) reported that the breakthrough time is decreased at 370 enhanced metal concentration.

371 Effect of dose (Bed height) on column scale $\mathrm{Pb}$ removal

372 Figure $3 \mathrm{c}$ presents the impact of bed height of PSB and CCB filled in the column for Pb removal

373 at steady state (constant flow rate) when column was wet packed with $3.0 \mathrm{~g}$ and $6.0 \mathrm{~g}$ PSB and

374 CCB separately. The impact of bed height was evaluated at constant initial $\mathrm{Pb}$ concentration (25

$375 \mathrm{mg} / \mathrm{L}$ ) and flow rate $2.5 \mathrm{ml} / \mathrm{min}$. The results revealed that when dose was changed from 3.0 to 6.0

$376 \mathrm{~g} /$ column, there was improvement in $\mathrm{Pb}$ removal at a given time which is attributed to higher

377 number of adsorption sites and more height of bed for the attachment of $\mathrm{Pb}$ at higher dosage (6.0

$378 \mathrm{~g} /$ column which is equal to $1.2 \mathrm{~cm}$ bed height) as compared with $3.0 \mathrm{~g} / \mathrm{column}$ which is equal to

$3790.65 \mathrm{~cm} /$ column. The PSB and CCB showed 63.4\% and 50.8\% $\mathrm{Pb}$ removal, respectively at dose

$3803.0 \mathrm{~g} /$ column while at higher dose (6.0 g/column), PSB and CCB showed higher removal (73.2\%

381 and 59.3\%, respectively). The increase in bed height results in more service time for breakthrough

382 curve and exhaustion time for a given concentration (Naeem et al. 2020; Imran et al. 2021; Yaya

383 et al. 2020; Canteli et al. 2014). Bharathi and Ramesh (2013) reported that the removal increased

384 with increasing bed height/dose. It is attributed to more adsorption sites available for the

385 contaminant sequestration. El-Mouhri et al. (2020) observed that the removal enhanced from

$38695.4 \%-97.4 \%$ when the bed height was increased from $3-5 \mathrm{~cm}$. The increase in removal

387 percentage is attributed to the active sites and interaction time available for the contaminant with

388 the adsorbent material. Swapna Priya and Radha (2016) studied that the quantity of adsorbent is

389 very crucial for the breakthrough point because adsorbent quantity determines the bed height. As

390 bed height is increased, the breakthrough would also be higher because increase in bed height

391 increases the surface area significantly which favors the adsorption.

392 Batch scale $\mathbf{P b}$ sequestration from contaminated water

393 Impact of initial Pb level on its adsorption and removal

394 The impact of various concentrations of $\mathrm{Pb}$ with constant adsorbent mass on $\mathrm{Pb}$ removal (\%) are

395 shown in Figure 4a. Figure 4a depicted that the $\mathrm{Pb}$ removal decreased with the increasing initial

$396 \mathrm{~Pb}$ concentration in contaminated water. For PSB, a sharp decrease was observed from 90.0 to

$39779.8 \%$ when the solution initial concentration was changed from 25 to $50 \mathrm{mg} / \mathrm{L}$. While for CCB 
398 under same conditions, a decline in $\mathrm{Pb}$ removal from 79-2-52.5\% was observed. It was attributed

399 to the limited number of active available sites for the removal of $\mathrm{Pb}$ from contaminated water. As

400 the solution initial concentration increased, there is more competition between adsorbent and

401 adsorbate. At lower initial concentration, the removal was highest because PSB contains enough

402 available spaces that favors the adsorption of Pb on PSB and $\mathrm{CCB}$. While at higher concentration,

403 the available spaces become saturated with $\mathrm{Pb}$ ions and no more sites are available for the

404 adsorption of $\mathrm{Pb}$ ions. The decline in the $\mathrm{Pb}$ removal with increasing solution concentration is

405 attributed to the concentration gradient or split in the flux in solute concentration and sorbent

406 surface. The decline in removal with increasing concentration was due to the decline in available

407 sorption sites (Boudrahem et al. 2019). Alatabe and Al-Sharify (2019) reported that the rapid

408 adsorption of $\mathrm{Pb}$ at lower concentration. While with the increasing concentration of $\mathrm{Pb}$ the

409 adsorption decreased, which is due to the $\mathrm{Pb}$ ions adsorbed on the outer surface of the adsorbent.

410 Furthermore, enhanced initial solution concentration of $\mathrm{Pb}$ resulted into fast saturation of sorbent

411 materials..

\section{Impact of adsorbent dose on Pb removal}

413 Figure $4 \mathrm{~b}$ depicted that effect of PSB and CCB adsorbents dose for the removal of $\mathrm{Pb}$ from 414 contaminated water by varying adsorbent dose from 1.25 to $5.0 \mathrm{~g} / \mathrm{L}$ of contaminated water when

$415 \mathrm{~Pb}$ initial concertation was $50 \mathrm{mg} / \mathrm{L}$. Results revealed a clear impact of PSB and CCB biomass on

$416 \mathrm{~Pb}$ removal (Figure $4 \mathrm{~b}$ ). The maximum values of $\mathrm{Pb}$ ion sorbed on PSB and CCB surface were

417 found at mass of $1.25 \mathrm{~g} / \mathrm{L}$ of contaminated water. Overall, $\mathrm{Pb}$ adsorption showed a decline with

418 the increase when adsorbent dose was increased. As adsorbent dose is increased, surface area also

419 increases and the interaction between $\mathrm{Pb}$ and adsorbent becomes strong therefore, the removal

420 increased with increasing adsorbent dosage. Initially, a sharp increase (45.4\% to $79.8 \%)$ in $\mathrm{Pb}$

421 removal was observed By PSB when dosage was changed from 1.25 to $2.5 \mathrm{~g} / \mathrm{L}$ of Pb contaminated

422 water. While with the further increase in adsorbent dosage the impact was small (79.8-87.6\%)

423 which is due to the possible aggregation of adsorbent particles at higher dose (Imran et al. 2021).

424 Similarly, Iqbal et al. (2021) reported that with the addition of adsorbent dosage the removal was

425 elevated which is attributed to the competition between adsorbent and adsorbate. Initially there are

426 limited number of active available sites and higher number of contaminant ions therefore, the

427 removal was decreased. Moreover, at lower adsorbent dosage the active sites becomes saturated 
428 with contaminant earlier (Imran et al. 2020). At higher adsorbent dosage, the removal was not 429 significantly increased which is due to the overlapping/aggregation of adsorbent material at higher 430 concentration of dose (Wang et al. 2018). Similar results were reported by many researchers 431 (Adenuga et al. 2019; Heraldy et al. 2018; Iqbal et al. 2021; Kostić et al. 2014).

\section{Effect of interaction time on $\mathrm{Pb}$ removal}

433 Effective adsorption is reflected when the equilibrium is attained with adsorbent and adsorbate. 434 Furthermore, a certain time is crucial that confirms that the equilibrium has been attained (Dakhil 435 2015). Therefore, impact of interaction time was evaluated as a main parameter that affects the 436 adsorption capacity of PSB and CCB adsorbents. Figure 5a displays the behavior of Pb removal 437 with different time interval on PSB and CCB at constant $\mathrm{pH}-6$, dose $2.5 \mathrm{~g} / \mathrm{L}$, and concentration 50 $438 \mathrm{mg} / \mathrm{L}$. Adsorption of $\mathrm{Pb}$ increased when interaction time was increased but a significant changes 439 happened in first 30 minutes, subsequently minor variations in adsorption were noted. The 440 adsorption of $\mathrm{Pb}$ ions became constant when at equilibrium (60 min) by both PSB and CCB 441 adsorbents. At equilibrium, highest $\mathrm{Pb}$ ions removal efficiency was $79.8 \%$ when $50 \mathrm{mg} \mathrm{Pb} / \mathrm{L}$ 442 interacted with PSB and CCB showed $48.80 \%$ removal under same conditions. The increase in 443 removal with increasing interaction time is attributed to the interaction time between adsorbent 444 and $\mathrm{Pb}$ ions. Initially the adsorption sharply increased but with the passage of time, the $\mathrm{Pb}$ removal 445 was slower than initial period of time. After $60 \mathrm{~min}$, change in removal is low due to occupation 446 of most of the adsorption sites during first $60 \mathrm{~min}$. The removal onto PSB increased from 49.4 to $44773.0 \%$ when the interaction time was changed from 15 to $60 \mathrm{~min}$. Results show that when 448 interaction time further increased from 60 to $180 \mathrm{~min}$, only $6.8 \%$ more $\mathrm{Pb}$ was removed. Therefore, 449 experiment was run for $180 \mathrm{~min}$ to attain equilibrium. Mukherjee et al. (2020) reported that the Pb 450 and $\mathrm{Cd}$ removal gradually increased with increasing interaction time and then a sharp decline was 451 noticed after $30 \mathrm{~min}$, which is due to the intra-particle diffusion process. Similarly, Gaur et al.

452 (2018) reported that the equilibrium was attained in first $60 \mathrm{~min}$ for the adsorption of $\mathrm{Pb}$ and $\mathrm{As}$ 453 by using soya been biosorbent. The results were also consistent with other relevant studies 454 (Arimurti et al. 2016; Ben-Ali et al. 2017; Yogeshwaran and Priya 2021).

\section{Effect of solution $\mathbf{p H}$ on $\mathrm{Pb}$ removal}


456 In adsorption studies, $\mathrm{pH}$ plays an important role for the removal of contaminants from wastewater.

457 The impact of $\mathrm{pH}$ for the removal $\mathrm{Pb}$ onto PSB and $\mathrm{CCB}$ from contaminated water was evaluated.

458 Therefore, the solution $\mathrm{pH}$ was changed from 4 to 10, while all other parameters were kept constant

$459(50 \mathrm{mg} / \mathrm{L})$. Figure $5 \mathrm{~b}$ demonstrates the impact of $\mathrm{pH}$ on $\mathrm{Pb}$ removal from contaminated water. It 460 was noticed that with the increase in $\mathrm{pH}$, the removal percentage also increased. The removal 461 percentage with PSB changed from 62.0-79.9\% when the solution pH was increased from 4 to 6.

462 The increase in removal percentage is due to fluctuations in $\mathrm{pH}$ which might result from the surface

463 properties of the adsorbent material as well as contaminant molecules. Heraldy et al. (2018) 464 reported that the removal enhanced with the increasing $\mathrm{pH}$ of the $\mathrm{Pb}$ contaminated solution. 465 Previously reported that the effectiveness of the adsorbent materials were low at lower $\mathrm{pH}$ and 466 increased with increasing $\mathrm{pH}$ (Pang et al. 2011). This might be due to the fact that lower $\mathrm{pH}$ can 467 charge the active sites with $\mathrm{H}+$ ions and makes the adsorbent surface more positive that cause 468 electrostatic repulsion between adsorbent and $\mathrm{Pb}$ ions. Moreover, at basic $\mathrm{pH}$ electrostatic 469 attraction occurred between adsorbent and adsorbate and enhanced removal was obtained 470 (Hafshejani et al. 2015; Taşar et al. 2014). When the solution $\mathrm{pH}>6$, the $\mathrm{Pb}$ hydrolysis and 471 precipitation occurs as $\mathrm{Pb}$ hydroxides (Heraldy et al. 2018). As $\mathrm{pH}$ was further changed from 647210 , there is improvement of $\mathrm{Pb}$ removal but removal at $\mathrm{pH}$ beyond 6 is attributed to $\mathrm{Pb}$ precipitation 473 in solution as we observed clear precipitates at this higher $\mathrm{pH}$ (8 and 10). So, $\mathrm{pH}-6$ was selected 474 as optimum $\mathrm{pH}$ and all other cases were conducted at this $\mathrm{pH}$.

\section{Impact of coexisting ions on Pb removal}

476 The presence of competing ions in water may affect the contaminant removal onto the adsorbent 477 surface (Imran et al. 2019; Vilvanathan and Shanthakumar 2015). Figure 5 c presents the results 478 regarding the impact of cations and anions on the removal of $\mathrm{Pb}$ when initial $\mathrm{Pb}$ concentrations 479 (25 and $50 \mathrm{mg} / \mathrm{L}$ ) were developed in two groundwater samples (GW1 and GW2). The 480 characteristics of GW1 and GW2 are given in Table 1. The results (Figure 5c) reveal that $\mathrm{Pb}$ 481 removal with DW, GW1 and GW2 onto PSB at $25 \mathrm{mg} / \mathrm{L}$ was 90, 85.2 and 88.4\%, respectively 482 while PSB showed 79.8, 71.0 and 75.8\% Pb removal in DW, GW1 and GW2, respectively at 50 $483 \mathrm{mg} / \mathrm{L}$. The GW1 and GW2 showed $4.8 \%$ and $1.6 \%$ lower $\mathrm{Pb}$ removal than $\mathrm{DW}$ when experiment 484 was run at $25 \mathrm{mg} / \mathrm{L}$ while GW1 and GW2 showed 8.8 and 4.0\% less $\mathrm{Pb}$ removal as compared with $485 \mathrm{DW}$ at $50 \mathrm{mg} / \mathrm{L}$. Similarly, Pb removal with DW, GW1 and GW2 onto CCB at 25 mg/L was 70.2, 
48671.6 and 75.42, respectively while CCB showed 69.8, 60.0 and $64.4 \% \mathrm{~Pb}$ removal in DW, GW1 487 and GW2, respectively at $50 \mathrm{mg} / \mathrm{L}$. The GW1 and GW2 showed 7.6\% and 4.0\% lower Pb removal 488 than DW when experiment was run at $25 \mathrm{mg} / \mathrm{L}$ while GW1 and GW2 showed 9.8 and 5.4\% less $489 \mathrm{~Pb}$ removal as compared with $\mathrm{DW}$ at $50 \mathrm{mg} / \mathrm{L}$. The GW1 showed more difference in $\mathrm{Pb}$ removal 490 onto both PSB and CCB as compared with GW2. This higher difference in Pb removal by GW2 491 is attributed to higher concentration of cations ( $\mathrm{Na}, \mathrm{K}, \mathrm{Ca}$, and $\mathrm{Mg}$ ) as compared with GW1 (Table 492 1). The higher concentration of coexisting cations (especially $\mathrm{Ca}$ and $\mathrm{Mg}$ ) competed for adsorption 493 sites with $\mathrm{Pb}$ ions (Imran et al. 2019; Meseguer et al. 2016) to occupy the surface of PSB and CCB 494 adsorbents. Similar response of competing ions in groundwater was found by Imran et al. (2019) 495 on the removal of $\mathrm{Pb}$ from contaminated water. Likewise, many other studies have reported that 496 with increasing ionic strength the removal decreased (Imran et al. 2020; Imran et al. 2021; Kariuki 497 et al. 2017).

498 Equilibrium and kinetic isotherms for Pb adsorption onto PSB

499 The equilibrium data for $\mathrm{Pb}$ adsorption by PSB and CCB was mathematically explained by 500 adsorption isotherm models as described earlier in section 2.7. The kinetic adsorption data obtained 501 at $50 \mathrm{mg} \mathrm{Pb} / \mathrm{L}$ was validated with PFO, PSO and Intra-particle diffusion model. The fitting 502 behavior of kinetic models has been displayed in Figure 6a-c. The comparison of modeling results 503 with kinetic experimental data shows that pseudo second order well explained the kinetic 504 adsorption of $\mathrm{Pb}$ onto PSB and CCB as is evident from the value of coefficient of determination $505\left(\mathrm{R}^{2}\right)$ which is 0.99 for Pseudo second order model. The values of kinetic and equilibrium model 506 parameters have been shown in Table 1. For equilibrium data, values of coefficient of 507 determination show that $\mathrm{Pb}$ ion sorption well fitted with Freundlich adsorption isotherm $\left(\mathrm{R}^{2}=0.98\right.$, 508 Table 1). The fitting behavior of equilibrium models (Langmuir and Freundlich) has been 509 presented in Figure 6d-e. The respective values of coefficient of determination $\mathrm{R}^{2}$ in case of

510 Langmuir adsorption isotherm fitted with PSB was 0.89 while adsorption by CCB was equally

511 fitted with Langmuir model as its $\mathrm{R}^{2}=0.98$. The value of $\mathrm{q}_{\max }$ for PSB and CCB as per Langmuir 512 model was $42.05 \mathrm{mg} / \mathrm{g}$ and $26.39 \mathrm{mg} / \mathrm{g}$, respectively. Moreover, respective $n$ values of Freundlich 513 model for PSB and CCB was 1.92 and 2.27.

514

\section{Comparison of Pb removal by PSB with literature}


516 A comparison of $\mathrm{Pb}$ adsorption onto PSB and CCB with previous studies is important to determine

517 the effectiveness and real time applications of proposed materials. Table 3 highlights the

518 comparison of PSB and CCB with previous studies. Current study depicted that the adsorption of

$519 \mathrm{~Pb}$ was $50.0 \mathrm{mg} / \mathrm{g}$. Hence, it was noticed that the proposed material (PSB) is more efficient than

520 other adsorbents such as corncobs (Mendoza-Castillo et al. 2015), soya bean (Gaur et al. 2018),

521 Eupatorium adenophorum spreng (Guo et al. 2009), Okra waste (Hashem 2007), Tea waste

522 (Mondal 2010), and Agave sisalana (Dos Santosa et al. 2011). It was also noticed that many other

523 adsorbents are available that have been more efficient such as tomato waste and apple juice residue

524 (Heraldy et al. 2018), lignin biosorbent (Klapiszewski et al. 2017), Pineapple waste (Mopoung and

525 Kengkhetkit 2016), Palm fruit fiber (Ideriah et al. 2012) etc. than PSB. However, the availability

526 and cost effectiveness of the adsorbent materials is also very important. Although many adsorbents

527 are more efficient, but the process and cost effectiveness makes PSB attractive for the remediation

528 of $\mathrm{Pb}$ from contaminated water.

529 Conclusions

530 In the present work, the fixed bed column and batch scale adsorption potential of Peanut shells and 531 commercial compost as biosorbents (PSB and CCB) were successfully evaluated for the 532 sequestration of $\mathrm{Pb}$ from contaminated work. The maximum adsorption of $\mathrm{Pb}$ onto PSB (42.5 $533 \mathrm{mg} / \mathrm{g})$ was higher than CCB $(26.39 \mathrm{mg} / \mathrm{g})$ at optimum dose and $\mathrm{pH}$, which is better than several 534 previously explored adsorbents. The more $\mathrm{Pb}$ sequestration onto PSB is attributed to its improved 535 surface characterization (SEM, FTIR, and BET) as compared with CCB under same conditions. 536 The presence of competing ions in groundwater (GW1 and GW2) showed 9.8 and $5.4 \%$ lower, $537 \mathrm{~Pb}$ removal by $\mathrm{CCB}$ as compared with distilled water while this difference was 8.8 and $4.0 \%$ by $538 \mathrm{PSB}$ when $50 \mathrm{mg} \mathrm{Pb} / \mathrm{L}$ was used under optimal conditions. The kinetic behavior of $\mathrm{Pb}$ adsorption 539 onto the adsorbents showed best fit with pseudo second order kinetic model $\left(\mathrm{R}^{2}=0.99\right)$ while 540 isothermal equilibrium adsorption onto PSB was best explained with Freundlich model $\left(\mathrm{R}^{2}=0.98\right)$, 541 however, $\mathrm{Pb}$ adsorption onto $\mathrm{CCB}$ was equally well explained with Langmuir and Freundlich 542 adsorption models. Column experiments showed excellent retention of $\mathrm{Pb}$ especially on PSB under 543 different flow rates, initial $\mathrm{Pb}$ concentration and dose of the adsorbents. It is concluded that PSB 544 is more effective and environment friendly at both column and batch scale for the removal of $\mathrm{Pb}$ 545 as compared with CCB 


\section{Acknowledgement}

547 Authors are thankful to COMSATS University Islamabad (CUI), Vehari Campus to providing

548 research facility and technical expertise. We are equally indebted to IRCBM, CUI Lahore-Campus

549 for the characterization of the biosorbents.

550

551

552

553

554

555

556

557

558

559

560

561

562

563

564

565

566

567

568

569

570

571

572

573

574

575

576

\section{References}

Alatabe, M.J.A. and Al-Sharify, Z.T. (2019). Utilization of low cost adsorbents for the adsorption process of lead ions. International Journal of Modern Research in Engineering Technology 4, 29-48.

Adenuga, A.A., Amos, O.D., Oyekunle, J.A.O. and Umukoro, E.H. (2019). Adsorption performance and mechanism of a low-cost biosorbent from spent seedcake of Calophyllum inophyllum in simultaneous cleanup of potentially toxic metals from industrial wastewater. Journal of Environmental Chemical Engineering 7, 103317.

Arimurti, D.D., Heraldy, E. and Lestari, W.W. (2016). Biosorption of lead (II) ions by NaOHactivated apple (Malus domestica) juice residue. In AIP conference proceedings, Volume 1710. (AIP Publishing LLC), p. 030036.

Arunlertaree, C., Kaewsomboon, W., Kumsopa, A., Pokethitiyook, P. and Panyawathanakit, P. (2007). Removal of lead from battery manufacturing wastewater by egg shell.

Ben-Ali, S., Jaouali, I., Souissi-Najar, S. and Ouederni, A. (2017). Characterization and adsorption capacity of raw pomegranate peel biosorbent for copper removal. Journal of Cleaner Production 142, 3809-3821.

Bharathi, K.S. and Ramesh, S.P.T. (2013). Fixed-bed column studies on biosorption of crystal violet from aqueous solution by Citrullus lanatus rind and Cyperus rotundus. Applied Water Science 3, 673-687. 
577

578

579

580

581

582

583

584

585

586

587

588

589

590

591

592

593

594

595

596

597

598

599

600

601

602

603

604

605

606

607

608

609

610

611

612

Boudrahem, F., Aissani-Benissad, F., Audonnet, F. and Vial, C. (2019). Effects of acid-basic treatments of date stones on lead (II) adsorption. Separation Science Technology 54, 17491763 .

Dakhil, I.H. (2015). Adsorption of Lead from Industrial Effluents using Rice Husk. International Journal of Engineering Management Research 5, 109-116.

Dorado, A.D., Gamisans, X., Valderrama, C., Solé, M. and Lao, C. (2014). Cr (III) removal from aqueous solutions: a straightforward model approaching of the adsorption in a fixed-bed column. Journal of Environmental Science Health, Part A 49, 179-186.

Dos Santosa, W., Cavalcante, D., Da Silva, E., Das Virgens, C. and de Souza Dias, F. (2011). Biosorption of $\mathrm{Pb}$ (II) and $\mathrm{Cd}$ (II) ions by Agave sisalana (sisalv fiber). Microchem. J 97, 269-273.

El Mouhri, G., Merzouki, M., Belhassan, H., Miyah, Y., Amakdouf, H., Elmountassir, R. and Lahrichi, A. (2020). Continuous Adsorption Modeling and Fixed Bed Column Studies: Adsorption of Tannery Wastewater Pollutants Using Beach Sand. Journal of Chemistry 2020.

Gaur, N., Kukreja, A., Yadav, M. and Tiwari, A. (2018). Adsorptive removal of lead and arsenic from aqueous solution using soya bean as a novel biosorbent: equilibrium isotherm and thermal stability studies. Applied Water Science 8, 1-12.

Guo, S., Li, W., Zhang, L., Peng, J., Xia, H. and Zhang, S. (2009). Kinetics and equilibrium adsorption study of lead (II) onto the low cost adsorbent-Eupatorium adenophorum spreng. Process Safety Environmental Protection 87, 343-351.

Hafshejani, L.D., Nasab, S.B., Gholami, R.M., Moradzadeh, M., Izadpanah, Z., Hafshejani, S.B. and Bhatnagar, A. (2015). Removal of zinc and lead from aqueous solution by nanostructured cedar leaf ash as biosorbent. Journal of molecular liquids 211, 448-456.

Hashem, M.A. (2007). Adsorption of lead ions from aqueous solution by okra wastes. International Journal of Physical Sciences 2, 178-184.

Heraldy, E., Lestari, W.W., Permatasari, D. and Arimurti, D.D. (2018). Biosorbent from tomato waste and apple juice residue for lead removal. Journal of Environmental Chemical Engineering 6, 1201-1208.

Heraldy, E., Lestari, W.W., Permatasari, D. and Arimurti, D.D.E. (2018). Biosorbent from tomato waste and apple juice residue for lead removal. Journal of Environmental Chemical 6, 1201-1208.

Ideriah, T., David, O. and Ogbonna, D. (2012). Removal of heavy metal ions in aqueous solutions using palm fruit fibre as adsorbent. J Environ Chem Ecotoxicol 4, 82-90.

Imran, M., Khan, Z.U.H., Iqbal, M.M., Iqbal, J., Shah, N.S., Munawar, S., Ali, S., Murtaza, B., Naeem, M.A. and Rizwan, M. (2020). Effect of biochar modified with magnetite 
613

614

615

616

617

618

619

620

621

622

623

624

625

626

627

628

629

630

631

632

633

634

635

636

637

638

639

640

641

642

643

644

645

646

647

648

649

nanoparticles and $\mathrm{HNO} 3$ for efficient removal of $\mathrm{Cr}(\mathrm{VI})$ from contaminated water: A batch and column scale study. Environmental Pollution 261, 114231.

Imran, M., Iqbal, M.M., Iqbal, J., Shah, N.S., Khan, Z.U.H., Murtaza, B., Amjad, M., Ali, S. and Rizwan, M. (2021). Synthesis, characterization and application of novel mno and cuo impregnated biochar composites to sequester arsenic (As) from water: modeling, thermodynamics and reusability. Journal of Hazardous Materials 401, 123338.

Iqbal, M.M., Imran, M., Ali, B., Nawaz, M., Siddique, M.H., Al-Kahtani, A.A., Hussain, K., Murtaza, B., Shah, N.S. and Khan, Z.U.H. (2021). Nanocomposites of sedimentary material with $\mathrm{ZnO}$ and magnetite for the effective sequestration of arsenic from aqueous systems: Reusability, modeling and kinetics. Environmental Technology Innovation 21, 101298.

Iqbal, M.M., Imran, M., Ali, B., Nawaz, M., Siddique, M.H., Al-Kahtani, A.A., Hussain, K., Murtaza, B., Shah, N.S., Khan, Z.U.H. et al. (2021). Nanocomposites of sedimentary material with $\mathrm{ZnO}$ and magnetite for the effective sequestration of arsenic from aqueous systems: Reusability, modeling and kinetics. Environmental Technology 21, 101298.

Kariuki, Z., Kiptoo, J. and Onyancha, D. (2017). Biosorption studies of lead and copper using rogers mushroom biomass 'Lepiota hystrix'. South african journal of chemical engineering $23,62-70$.

Klapiszewski, Ł., Bartczak, P., Szatkowski, T. and Jesionowski, T. (2017). Removal of lead (II) ions by an adsorption process with the use of an advanced SiO2/lignin biosorbent. Polish Journal of Chemical Technology 19.

Kostić, M., Radović, M., Mitrović, J., Antonijević, M., Bojić, D., Petrović, M. and Bojić, A. (2014). Using xanthated Lagenaria vulgaris shell biosorbent for removal of $\mathrm{Pb}$ (II) ions from wastewater. Journal of the Iranian Chemical Society 11, 565-578.

Mendoza-Castillo, D., Rojas-Mayorga, C., García-Martínez, I., Pérez-Cruz, M., HernándezMontoya, V., Bonilla-Petriciolet, A., Montes-Morán, M.S. and Technology (2015). Removal of heavy metals and arsenic from aqueous solution using textile wastes from denim industry. International Journal of Environmental Studies 12, 1657-1668.

Mondal, M.K. (2010). Removal of $\mathrm{Pb}$ (II) from aqueous solution by adsorption using activated tea waste. Korean journal of chemical engineering 27, 144-151.

Mopoung, R. and Kengkhetkit, N. (2016). Lead and cadmium removal efficiency from aqueous solution by $\mathrm{NaOH}$ treated pineapple waste. International Journal of Applied Chemistry 12, 23-35.

Mukherjee, S., Kumari, D., Joshi, M., An, A.K. and Kumar, M. (2020). Low-cost bio-based sustainable removal of lead and cadmium using a polyphenolic bioactive Indian curry leaf (Murraya koengii) powder. International journal of hygiene environmental health engineering 226, 113471.

Peer] Phy. Chem. reviewing PDF | (PCHEM-2021:07:64090:1:0:NEW 24 Nov 2021) 
650 Pang, Y., Zeng, G., Tang, L., Zhang, Y., Liu, Y., Lei, X., Li, Z., Zhang, J. and Xie, G. (2011). PEI-

651

652

653

654

655

656

657

658

659

660

661

662

663

664

665

666

667

668

669

670

671

672

673

674

675

676

677

678

679

680

681

682

683

684

685 grafted magnetic porous powder for highly effective adsorption of heavy metal ions. Desalination 281, 278-284.

Swapna Priya, S. and Radha, K. (2016). Fixed-bed column dynamics of tetracycline hydrochloride using commercial grade activated carbon: comparison of linear and nonlinear mathematical modeling studies. Desalination Water Treatment 57, 18964-18980.

Taşar, Ş., Kaya, F. and Özer, A. (2014). Biosorption of lead (II) ions from aqueous solution by peanut shells: equilibrium, thermodynamic and kinetic studies. Journal of Environmental Chemical Engineering 2, 1018-1026.

Wang, G., Zhang, S., Yao, P., Chen, Y., Xu, X., Li, T. and Gong, G. (2018). Removal of Pb (II) from aqueous solutions by Phytolacca americana L. biomass as a low cost biosorbent. Arabian Journal of Chemistry 11, 99-110.

Xu, Z., Cai, J.-g. and Pan, B.-c. (2013). Mathematically modeling fixed-bed adsorption in aqueous systems. Journal of Zhejiang University SCIENCE A 14, 155-176.

Yahya, M., Aliyu, A., Obayomi, K., Olugbenga, A. and Abdullahi, U. (2020). Column adsorption study for the removal of chromium and manganese ions from electroplating wastewater using cashew nutshell adsorbent. Cogent Engineering 7, 1748470.

Yogeshwaran, V. and Priya, A. (2021). Adsorption of lead ion concentration from the aqueous solution using tobacco leaves. Materials Today: Proceedings 37, 489-496.

Arunlertaree, C., Kaewsomboon, W., Kumsopa, A., Pokethitiyook, P. and Panyawathanakit, P. (2007). Removal of lead from battery manufacturing wastewater by egg shell.

Dos Santosa, W., Cavalcante, D., Da Silva, E., Das Virgens, C. and de Souza Dias, F. (2011). Biosorption of $\mathrm{Pb}$ (II) and Cd (II) ions by Agave sisalana (sisalv fiber). Microchem. J 97, 269-273.

Gaur, N., Kukreja, A., Yadav, M. and Tiwari, A. (2018). Adsorptive removal of lead and arsenic from aqueous solution using soya bean as a novel biosorbent: equilibrium isotherm and thermal stability studies. Applied Water Science 8, 1-12.

Gour, A., Sharma, A.K., Sharma, S. and Verma, S. (2016). Removal of Lead from aqueous solutions by adsorption on melon peel. IJCS 4, 123-125.

Guo, S., Li, W., Zhang, L., Peng, J., Xia, H. and Zhang, S. (2009). Kinetics and equilibrium adsorption study of lead (II) onto the low cost adsorbent-Eupatorium adenophorum spreng. Process Safety Environmental Protection 87, 343-351.

Hashem, M.A. (2007). Adsorption of lead ions from aqueous solution by okra wastes. International Journal of Physical Sciences 2, 178-184.

Hegazi, H. (2013). Removal of heavy metals from wastewater using agricultural and industrial wastes as adsorbents. HBRC J 9: 276-282. 
686

687

688

689

690

691

692

693

694

695

696

697

698

699

700

701

702

703

704

705

706

707

708
Heraldy, E., Lestari, W.W., Permatasari, D. and Arimurti, D.D. (2018). Biosorbent from tomato waste and apple juice residue for lead removal. Journal of Environmental Chemical Engineering 6, 1201-1208.

Ideriah, T., David, O. and Ogbonna, D. (2012). Removal of heavy metal ions in aqueous solutions using palm fruit fibre as adsorbent. J Environ Chem Ecotoxicol 4, 82-90.

Klapiszewski, Ł., Bartczak, P., Szatkowski, T. and Jesionowski, T. (2017). Removal of lead (II) ions by an adsorption process with the use of an advanced SiO2/lignin biosorbent. Polish Journal of Chemical Technology 19.

Mendoza-Castillo, D., Rojas-Mayorga, C., García-Martínez, I., Pérez-Cruz, M., HernándezMontoya, V., Bonilla-Petriciolet, A., Montes-Morán, M.S. and Technology (2015). Removal of heavy metals and arsenic from aqueous solution using textile wastes from denim industry. International Journal of Environmental Studies 12, 1657-1668.

Mondal, M.K. (2010). Removal of $\mathrm{Pb}$ (II) from aqueous solution by adsorption using activated tea waste. Korean journal of chemical engineering 27, 144-151.

Mopoung, R. and Kengkhetkit, N. (2016). Lead and cadmium removal efficiency from aqueous solution by $\mathrm{NaOH}$ treated pineapple waste. International Journal of Applied Chemistry 12, 23-35.

Mwandira, W., Nakashima, K., Togo, Y., Sato, T. and Kawasaki, S. (2020). Cellulosemetallothionein biosorbent for removal of $\mathrm{Pb}$ (II) and $\mathrm{Zn}$ (II) from polluted water. Chemosphere 246, 125733.

Zamani, A., Shokri, R., Yaftian, M. and Parizanganeh, A. (2013). Adsorption of lead, zinc and cadmium ions from contaminated water onto Peganum harmala seeds as biosorbent. International Journal of Environmental Science Technology 10, 93-102. 


\section{Table $\mathbf{1}$ (on next page)}

Table 1: Characteristics of groundwater samples (GW1 and GW2) used to evaluate the impact of interfering inorganic ions on the removal of $\mathrm{Pb}$ (II) from contaminated water. 
1 Table 1: Characteristics of groundwater samples (GW1 and GW2) used to evaluate the impact of

2 interfering inorganic ions on the removal of $\mathrm{Pb}$ (II) from contaminated water.

\begin{tabular}{cccc}
\hline Parameter & Units & GW1 & GW2 \\
\hline $\mathrm{EC}$ & $\mathrm{dS} \mathrm{m}^{-1}$ & $1.85 \pm 0.15$ & $0.9 \pm 0.05$ \\
$\mathrm{TDS}$ & $\mathrm{mg} \mathrm{L}^{-1}$ & $850 \pm 10.1$ & $495 \pm 8.1$ \\
$\mathrm{Mg}$ & $\mathrm{mg} \mathrm{L}^{-1}$ & $25.5 \pm 1.7$ & $37 \pm 2$ \\
$\mathrm{Na}$ & $\mathrm{mg} \mathrm{L}^{-1}$ & $245 \pm 5.3$ & $60 \pm 3$ \\
$\mathrm{~K}$ & $\mathrm{mg} \mathrm{L}^{-1}$ & $5.1 \pm 1.1$ & $4 \pm 0.2$ \\
$\mathrm{Ca}$ & $\mathrm{mg} \mathrm{L}^{-1}$ & $65 \pm 2.1$ & $30.2 \pm 4$ \\
$\mathrm{CO}$ & $\mathrm{mg} \mathrm{L}^{-1}$ & $80 \pm 3.1$ & $45 \pm 4$ \\
$\mathrm{HCO}$ & $\mathrm{mg} \mathrm{L}^{-1}$ & $570 \pm 7$ & $232 \pm 8.4$ \\
$\mathrm{Cl}$ & $\mathrm{mg} \mathrm{L}^{-1}$ & $690 \pm 8.5$ & $490.4 \pm 8$ \\
$\mathrm{SO}_{4}$ & $\mathrm{mg} \mathrm{L}^{-1}$ & $430 \pm 6$ & $355 \pm 7.5$ \\
$\mathrm{NO}_{3}$ & $\mathrm{mg} \mathrm{L}^{-1}$ & $30.5 \pm 3.4$ & $45.3 \pm 5$ \\
$\mathrm{~Pb}(\mathrm{II})$ & $\mu g^{-1}$ & $80 \pm 1.6$ & $57 \pm 3.2$ \\
\hline
\end{tabular}

3 


\section{Table 2 (on next page)}

Table 2: Parameters of kinetic and equilibrium adsorption models 
1 Table 2: Parameters of kinetic and equilibrium adsorption models

2

\begin{tabular}{|c|c|c|c|c|}
\hline Type & Model & Parameter & PSB & CCB \\
\hline \multirow{6}{*}{$\begin{array}{l}\text { Equilibrium } \\
\text { Adsorption } \\
\text { models }\end{array}$} & \multirow{3}{*}{ Langmuir } & $K_{L}(L / m g)$ & 0.080 & 0.077 \\
\hline & & $q_{\max }(m g / g)$ & 42.5 & 26.39 \\
\hline & & $R^{2}(-)$ & 0.89 & 0.99 \\
\hline & \multirow{3}{*}{ Freundlich } & $K_{F}\left(\left[m g / g(L / m g)^{1 / n}\right]\right)$ & 5.36 & 3.96 \\
\hline & & $n(-)$ & 1.92 & 2.27 \\
\hline & & $R^{2}(-)$ & 0.98 & 0.99 \\
\hline \multirow{9}{*}{$\begin{array}{l}\text { Kinetic } \\
\text { models }\end{array}$} & \multirow{3}{*}{$\begin{array}{l}\text { Pseudo first } \\
\text { order }\end{array}$} & $k_{1}(1 / \mathrm{min}) \times 10^{-2}$ & 0.046 & 0.069 \\
\hline & & $q_{e}(m g / g)$ & 9.58 & 5.47 \\
\hline & & $R^{2}(-)$ & 0.889 & 0.92 \\
\hline & \multirow{3}{*}{$\begin{array}{l}\text { Pseudo second } \\
\text { order }\end{array}$} & $k_{2}(\mathrm{~g} / \mathrm{mg} / \mathrm{min}) \times 10^{-2}$ & 0.0075 & 0.0028 \\
\hline & & $q_{e}(m g / g)$ & 16.7 & 15.6 \\
\hline & & $R^{2}(-)$ & 0.99 & 0.99 \\
\hline & \multirow{3}{*}{$\begin{array}{l}\text { Intra-particle } \\
\text { diffusion }\end{array}$} & $k_{\text {dif }}$ & 0.51 & 0.83 \\
\hline & & $C$ & 9.85 & 4.11 \\
\hline & & $R^{2}(-)$ & 0.67 & 0.77 \\
\hline
\end{tabular}




\section{Table 3 (on next page)}

Table 3: Comparison of different adsorbents for the removal of $\mathrm{Pb}$ from contaminated water 
1 Table 3: Comparison of different adsorbents for the removal of $\mathrm{Pb}$ from contaminated water

\begin{tabular}{|c|c|c|c|}
\hline No. & Materials & Adsorption/Removal & References \\
\hline 1 & lignin biosorbent & $89.02 \mathrm{mg} / \mathrm{g}$ & $\begin{array}{c}\text { (Klapiszewski et al. } \\
\text { 2017) }\end{array}$ \\
\hline 2 & soya bean & $0.72 \mathrm{mg} / \mathrm{g}$ & (Gaur et al. 2018) \\
\hline 3 & Pineapple waste & $77.16 \mathrm{mg} / \mathrm{g}$ & $\begin{array}{c}\text { (Mopoung and } \\
\text { Kengkhetkit 2016) }\end{array}$ \\
\hline 4 & Melon peel & $72 \mathrm{mg} / \mathrm{g}$ & (Gour et al. 2016) \\
\hline 5 & Palm fruit fiber & $73 \mathrm{mg} / \mathrm{g}$ & (Ideriah et al. 2012) \\
\hline 6 & metallothionein & $39.02 \mathrm{mg} / \mathrm{g}$ & (Mwandira et al. 2020) \\
\hline 7 & Modified corncobs & $4.34 \mathrm{mg} / \mathrm{g}$ & $\begin{array}{c}\text { (Mendoza-Castillo et } \\
\text { al. 2015) }\end{array}$ \\
\hline 8 & Okra waste & $5.00 \mathrm{mg} / \mathrm{g}$ & (Hashem 2007) \\
\hline 9 & Agave sisalana & $1.34 \mathrm{mg} / \mathrm{g}$ & (Dos Santosa et al. \\
& & & 2011) \\
\hline 10 & Tea waste & $1.35 \mathrm{mg} / \mathrm{g}$ & (Mondal 2010) \\
\hline 11 & Eupatorium & $3.46 \mathrm{mg} / \mathrm{g}$ & (Guo et al. 2009) \\
\hline 12 & Peanut shells biosorbent & $50.0 \mathrm{mg} / \mathrm{g}$ & Current study \\
\hline
\end{tabular}


Figure 1

Figure 1: Schematic representation of column scale arrangement for $\mathrm{Pb}$ removal from water

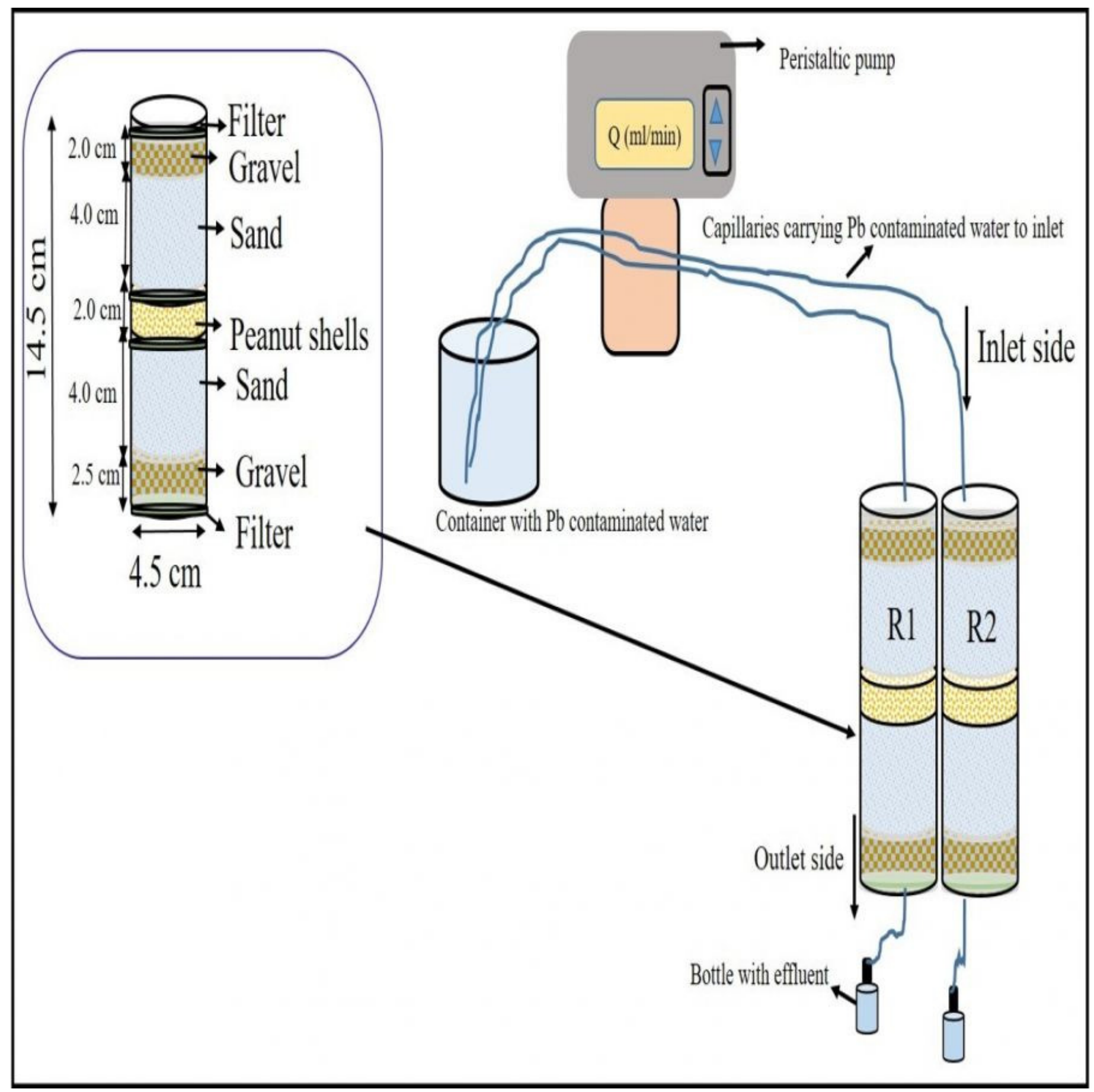




\section{Figure 2}

Figure 2: SEM image of Peanut shells (a), CCB (b) and (c) FTIR spectra of both adsorbents, (d) $\mathrm{N}_{2}$ adsorption/desorption during BET analysis of both CCB and PSB used for the removal of $\mathrm{Pb}$ from water at fixed bed column scale and batch scale
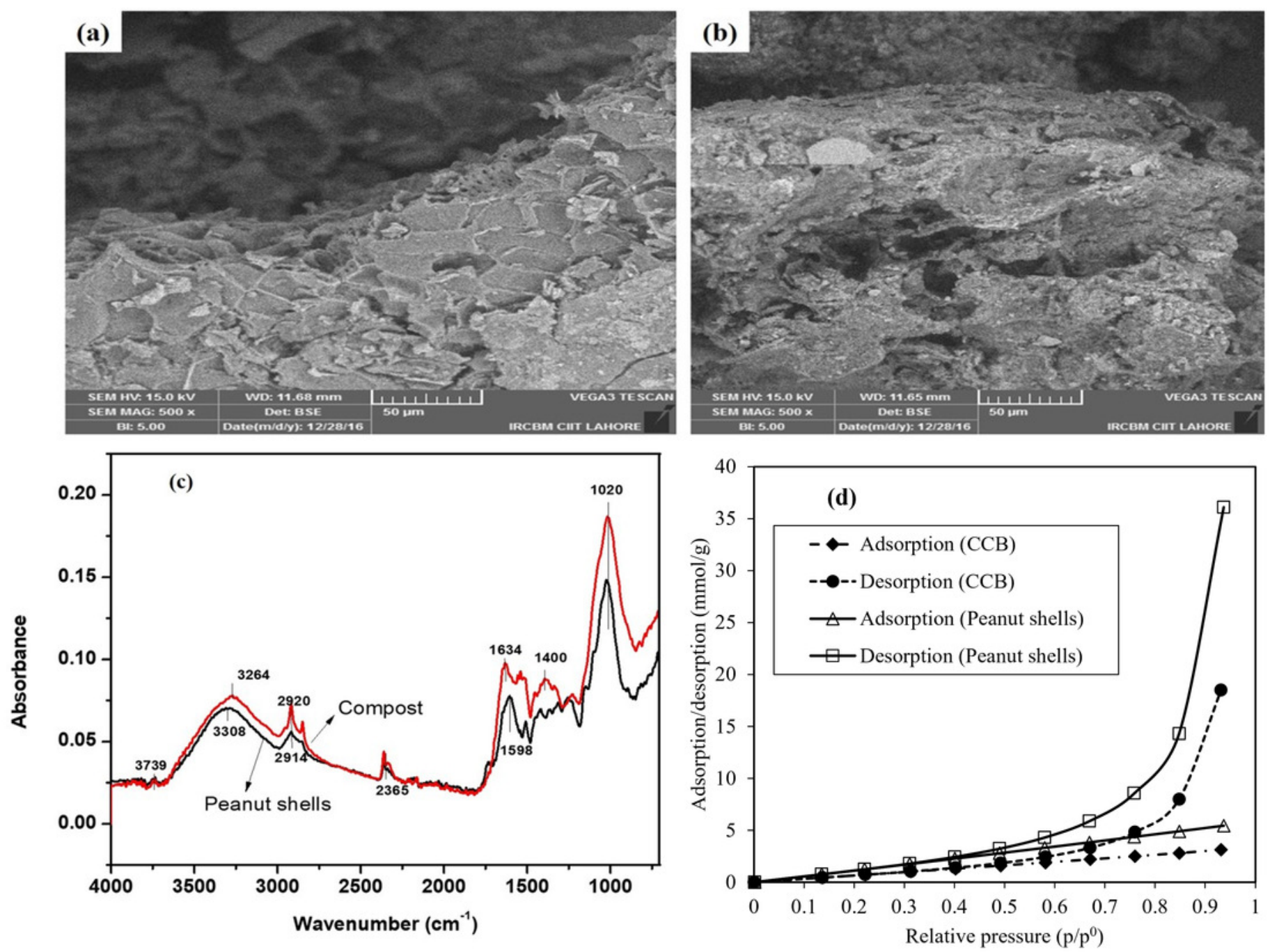
Figure 3

Figure 3: Breakthrough curves obtained from fixed bed column scale removal of $\mathrm{Pb}$ using Peanut shells (PSB) and commercial compost biosorbent (CCB); (a) effect of flow rate $(2.5$ and $5.0 \mathrm{ml} / \mathrm{min}$ ) when dose of PSB and CCB is $3.0 \mathrm{~g} /$ column $\mathrm{pH}-6$ and $\mathrm{Ci}=25$ $\mathrm{mg} / \mathrm{L}$,
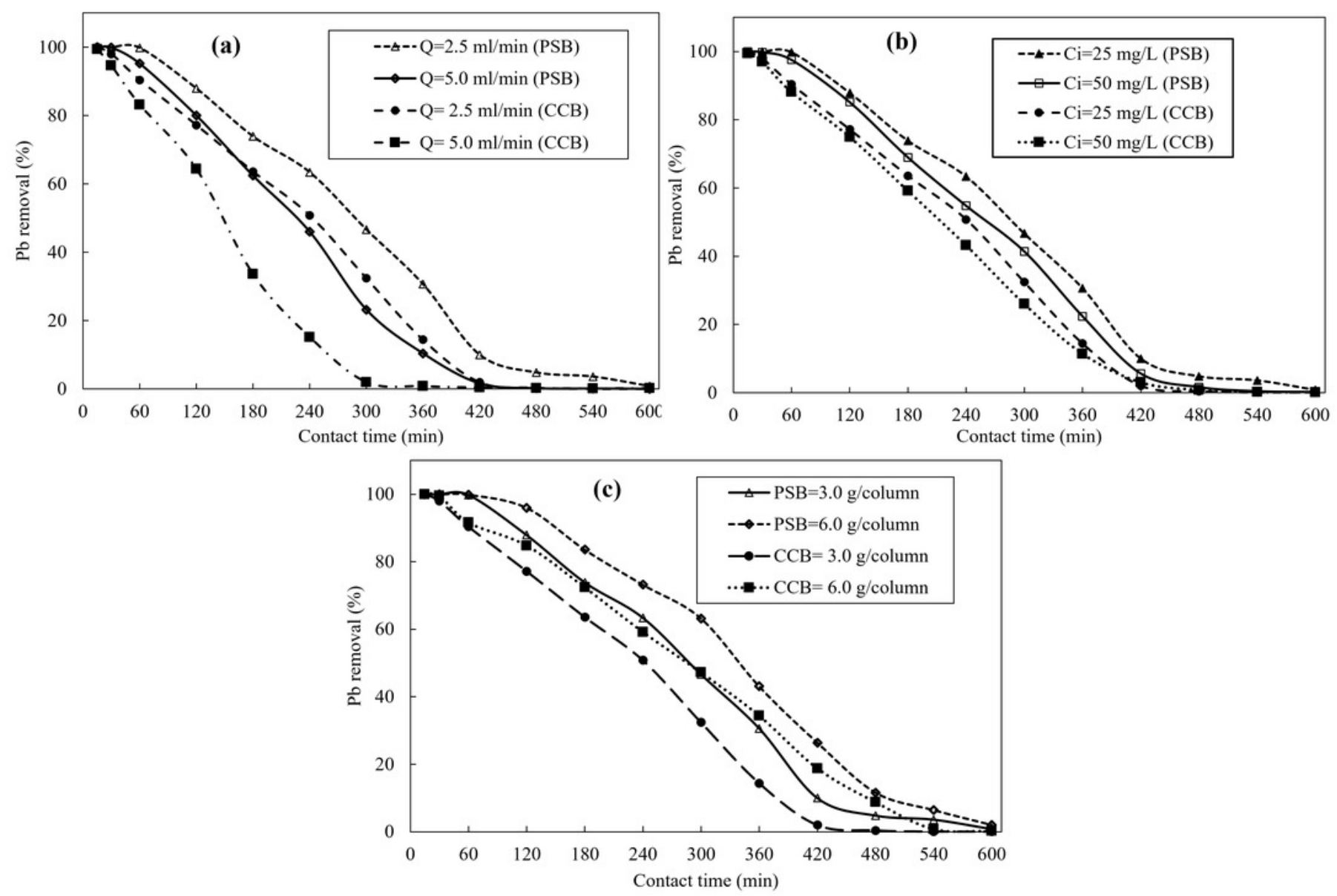


\section{Figure 4}

Figure 4: (a) Effect of initial concentration of $\mathrm{Pb}(25-100 \mathrm{mg} / \mathrm{L})$ on its removal (\%) at equilibrium, $\mathrm{pH}-6$, dose $0.5 \mathrm{~g} / \mathrm{L}$ and room temperature; (b) Impact of PSB and CCB dose on $\mathrm{Pb}$ removal at equilibrium, $\mathrm{Ci}=50 \mathrm{mg} / \mathrm{L}$, $\mathrm{pH}-6$; 

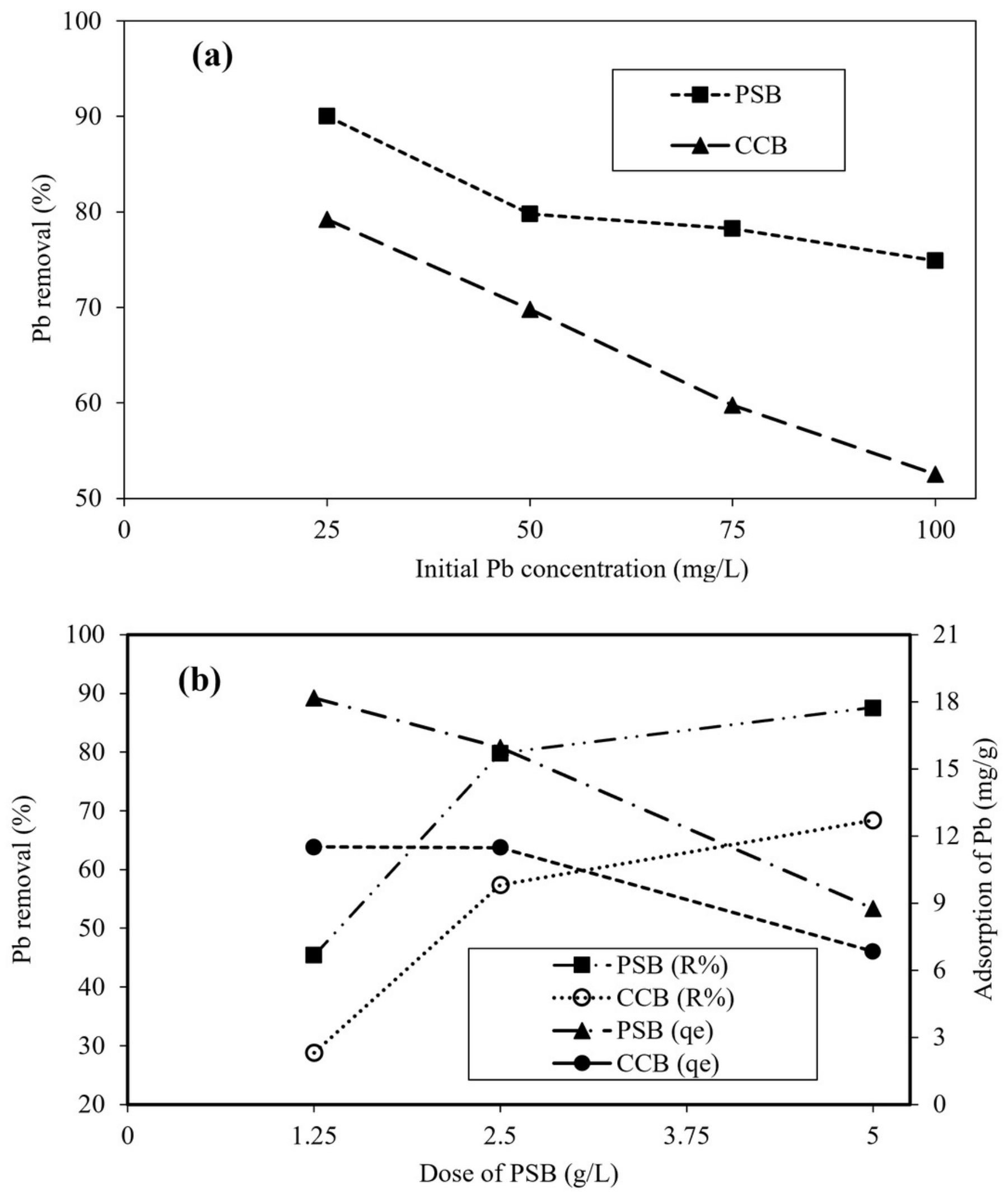
Figure 5

Figure 5: Effect of interaction time on (a) $\mathrm{Pb}$ removal when $\mathrm{Ci}=50 \mathrm{ppm}, \mathrm{PSB}$ dose $=0.5$ $\mathrm{g} / 100 \mathrm{ml}$ ), (b) impact of solution $\mathrm{pH}$ of contaminated water on $\mathrm{Pb}$ removal at equilibrium, dose $0.5 \mathrm{~g} / 100 \mathrm{ml}, \mathrm{Ci}=50 \mathrm{mg} / \mathrm{L}$, (c) impact of competing ions in groundwater sampl
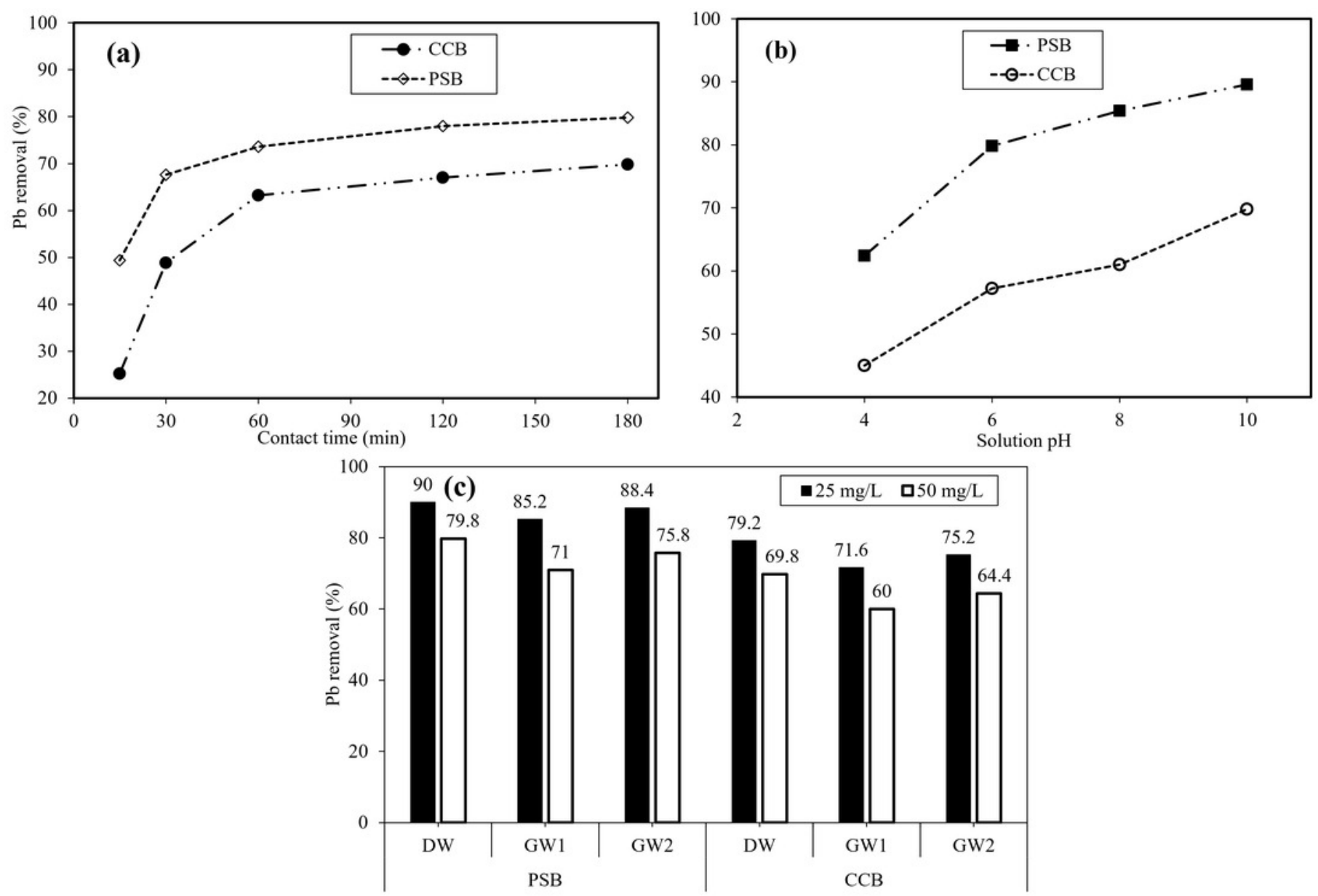
Figure 6

Figure 6: Correlation of experimental data with kinetic adsorption models: Pseudo first order (a), pseudo second order (b) and intra-particle diffusion (c); equilibrium adsorption isotherms: Langmuir (d), Freundlich (e).
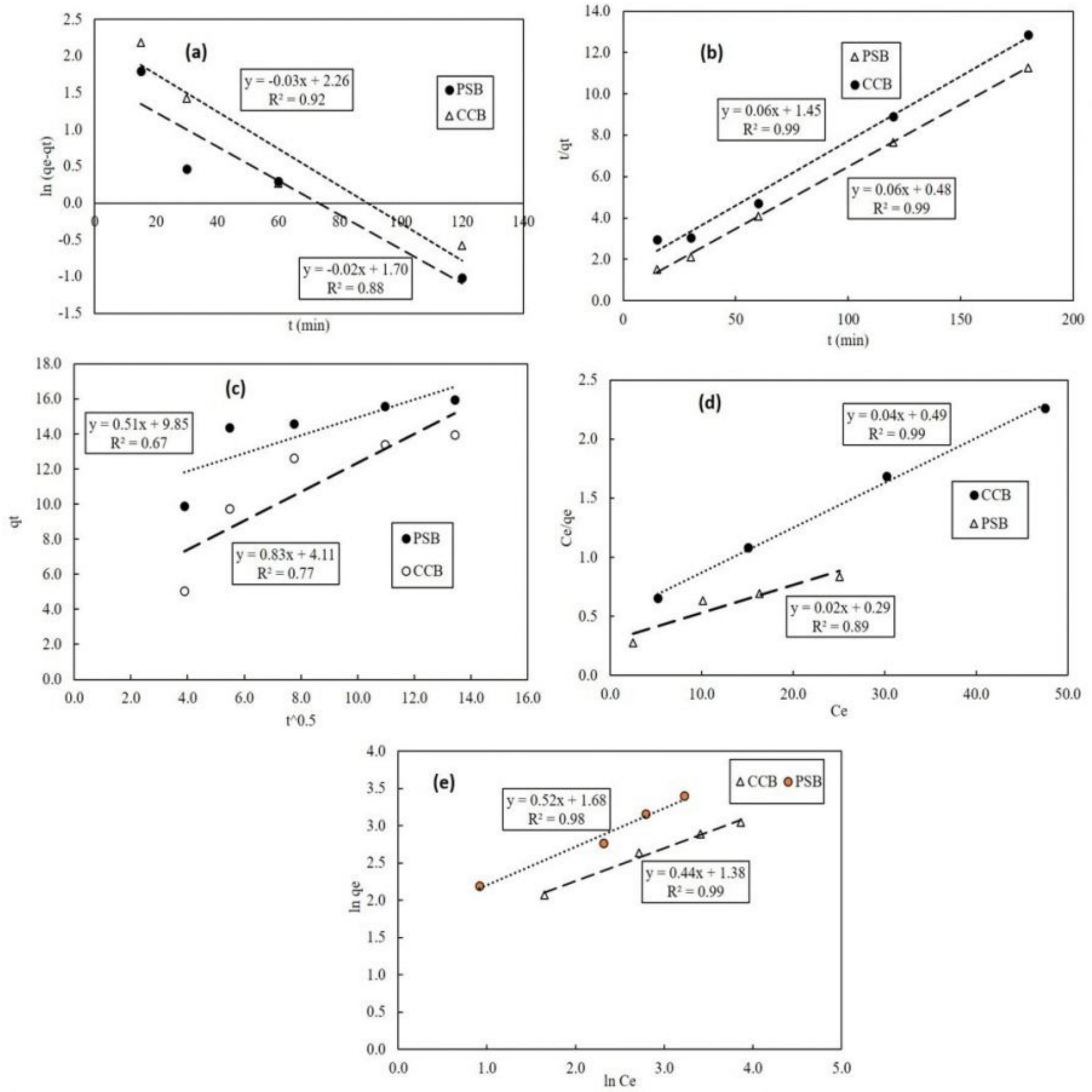